\title{
The Visible Hand: The Role of Government in China's Long-Awaited Industrial Revolution
}

\author{
Yi Wen and George E. Fortier
}

\begin{abstract}
China is undergoing its long-awaited industrial revolution. There is no shortage of commentary and opinion on this dramatic period, but few have attempted to provide a coherent, in-depth, politicaleconomic framework that explains the fundamental mechanisms behind China's rapid industrialization. This article reviews the New Stage Theory of economic development put forth by Wen (2016a). It illuminates the critical sequence of developmental stages since the reforms enacted by Deng Xiaoping in 1978: namely, small-scale commercialized agricultural production, proto-industrialization in the countryside, a formal industrial revolution based on mass production of labor-intensive light consumer goods, a sustainable "industrial trinity" boom in energy/motive power/infrastructure, and a second industrial revolution involving the mass production of heavy industrial goods. This developmental sequence follows essentially the same pattern as Great Britain's Industrial Revolution, despite sharp differences in political and institutional conditions. One of the key conclusions exemplified by China's economic rise is that the extent of industrialization is limited by the extent of the market. One of the key strategies behind the creation and nurturing of a continually growing market in China is based on this premise: The free market is a public good that is very costly for nations to create and support. Market creation requires a powerful "mercantilist" state and the correct sequence of developmental stages; China has been successfully accomplishing its industrialization through these stages, backed by measured, targeted reforms and direct participation from its central and local governments.
\end{abstract}

(JEL B00, H10, H40, H70, K00, L10, N00, O10, O20, O30, O40, O50, P00)

Federal Reserve Bank of St. Louis Review, Third Quarter 2016, 98(3), pp. 189-226.

http://dx.doi.org/10.20955/r.2016.189-226

\section{INTRODUCTION}

China's economic transformation has astonished the world. Even as recently as 20 years ago, few would have predicted China's dominance as a regional industrial power, let alone a global superpower. In merely one generation's time, China has created more productive forces than have the past 5,000 years of its previous dynasties and transformed from an impoverished

\footnotetext{
Yi Wen is an assistant vice president and economist in the Research Division of the Federal Reserve Bank of St. Louis. This article is based on his working paper from the Federal Reserve Bank of St. Louis (http://research.stlouisfed.org/wp/more/2015-006) and book (http://www.worldscientific.com/worldscibooks/10.1142/9885): The Making of an Economic Superpower-Unlocking China's Secret of Rapid Industrialization. George E. Fortier is the managing editor of the Federal Reserve Bank of St. Louis Review. The authors thank Alex Monge-Naranjo and David Wheelock for insightful and helpful comments.

○ 2016, Federal Reserve Bank of St. Louis. The views expressed in this article are those of the author(s) and do not necessarily reflect the views of the Federal Reserve System, the Board of Governors, or the regional Federal Reserve Banks. Articles may be reprinted, reproduced, published, distributed, displayed, and transmitted in their entirety if copyright notice, author name(s), and full citation are included. Abstracts, synopses, and other derivative works may be made only with prior written permission of the Federal Reserve Bank of St. Louis.
} 


\section{Figure 1}

\section{Manufacturing Output (1970-2014), Top 5 Countries in 2014}

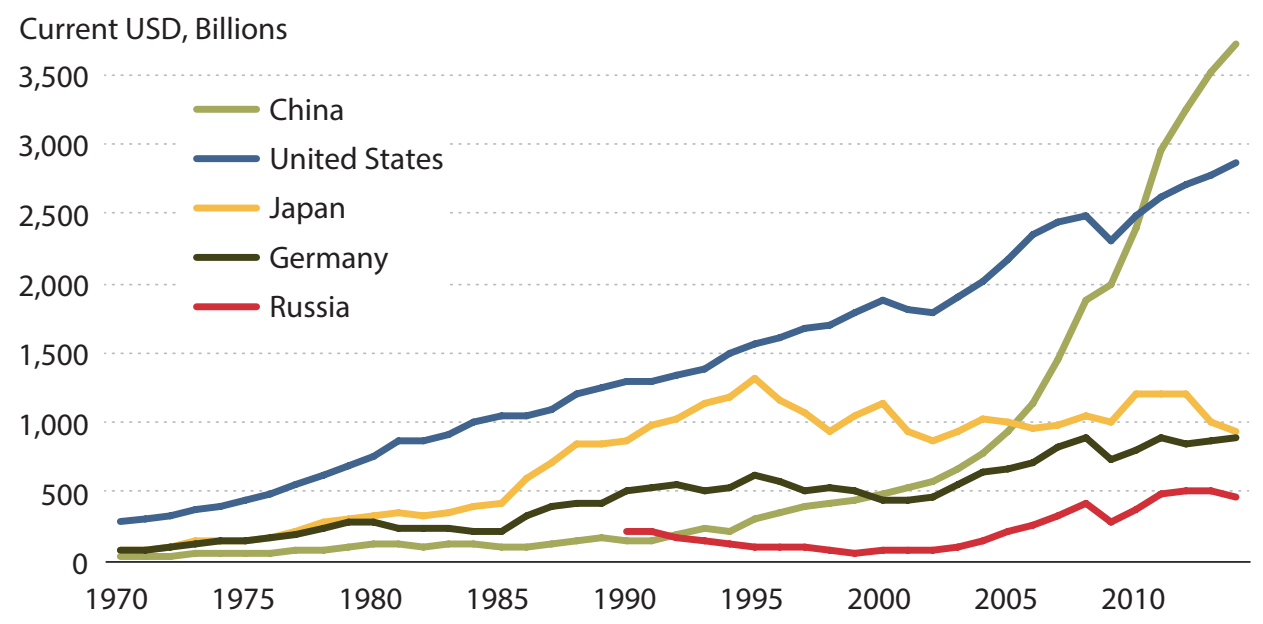

SOURCE: United Nations

Figure 2

\section{Patent Applications (1985-2014), Top 10 Countries in 2014}

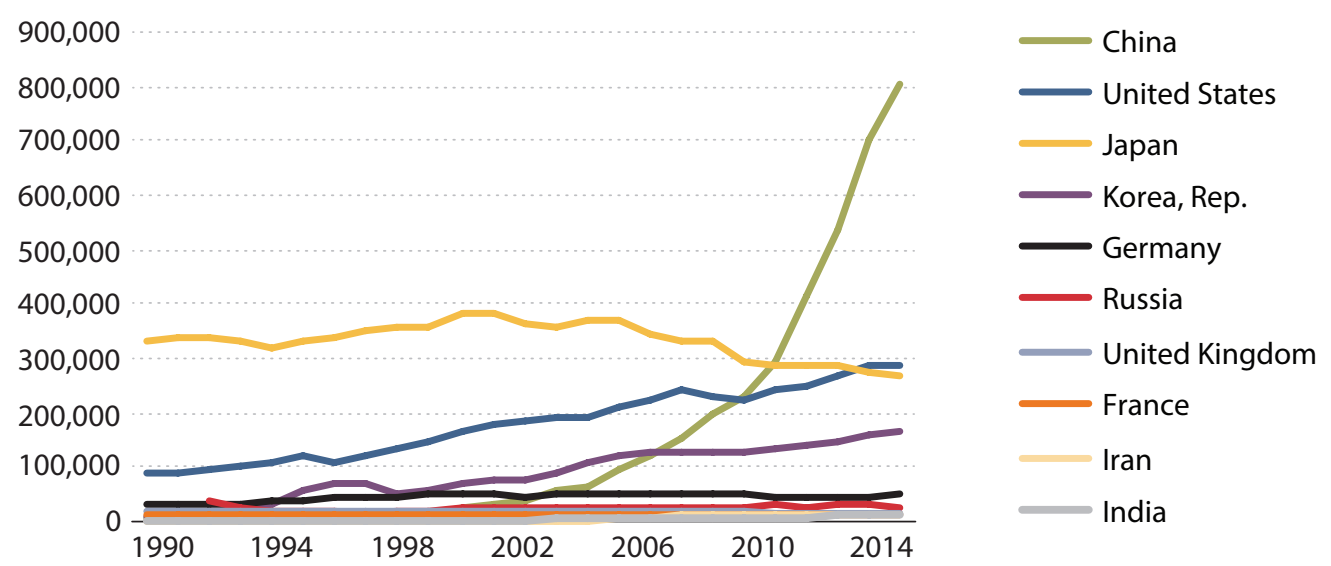

SOURCE: World Intellectual Property Organization (WIPO); see also Agence France-Presse (2014).

agrarian nation into the world's largest and most vigorous manufacturing powerhouse. (See Figure 1.)

In one year, China can produce 50 billion T-shirts (more than seven times the world's population), 10 billion pairs of shoes, 800 million metric tons of crude steel (50 percent of global supply and 800 percent of the U.S. level of production), 2.4 gigatons of cement (nearly 
60 percent of world production), and close to 4 trillion metric tons of coal (burning almost as much coal as the rest of the world combined). China is the world's largest producer of passenger cars, high-speed trains, ships, tunnels, bridges, highways, machine tools, cell phones, computers, robots, air conditioners, refrigerators, washing machines, furniture, fertilizer, agricultural crops, pork, fish, eggs, cotton, copper, aluminum, books, magazines, television shows, as well as college students (see Wen, 2016a).

Moreover, China is now the world's number one industrial patent applicant. For example, China's industrial patent applications were more than the sum of those in the United States and Japan in 2014. (See Figure 2.)

How did China achieve all this in a mere 35 years, when many observers were actually betting on its collapse? Critics called attention to the Tiananmen Square incident, the collapse of the Soviet Union and Eastern European communism, the Asian financial crisis, and the 2008 global recession, which cut China's total exports persistently by more than 40 percent below trend. Yet, China persisted through its industrial revolution and has achieved an astonishing 30-fold expansion of real GDP since 1978. This transformation was unexpected not merely because of China's pervasive backwardness after centuries of turmoil and economic regress, but also because of its enduring "extractive" and authoritarian political institutions. According to the new institutional theories of economic development, the existence of these obstacles predicted nothing but dismal failure for China. For example, the celebrated book, Why Nations Fail: The Origins of Power, Prosperity, and Poverty, articulates this perspective (Acemoglu and Robinson, 2012).

This skepticism does have some historical support: Since 1860, all of China's previous attempts at industrialization had failed. China in the 1950s, under the government of Mao Zedong, was on the threshold of true economic growth. Its state-owned enterprises at the time were motivated by the goal of rapidly catching up with the Western industrial powers, such as Great Britain and the United States. But China attempted to achieve this goal by fullfledged industrialization through central planning based on (i) "leapfrog" developmental strategies biased toward heavy industry and (ii) industrial policies of self-reliance and selfsufficiency. Yet this newly created industrial base produced goods to meet only very thin, limited domestic demand in China. Thus, these enterprises were highly unproductive and inefficient. Sustainable industrialization was once again out of reach.

Two decades later, in the late 1970s, China detonated a true industrial revolution. Today, China's government and firms are guided by well-known economic principles. But these are not contemporary principles; these are the well-known yet often-ignored principles of Adam Smith (Wealth of Nations, 1776). Smith explained the wealth of nations by the division of labor based on the size of the market, using examples from 18th century pin factories. More specifically, it has been China's approach to creating markets that has laid the foundation for its success. Instead of taking as given the neoclassical assumption that the free market automatically exists (and would be automatically created by free individuals on the supply side in the absence of any government effort or intervention), the Chinese government has taken the initiative and expended enormous effort to create both domestic and international markets for Chinese firms. This approach is analogous to what the European monarchies and powerful 


\section{Wen and Fortier}

merchants (such as the English East India Company) in the 16th to 18th centuries had done since the Age of Discovery, including the colonization of the Americas.

Unlike the European nations of the 16th to 18th centuries, however, China in the late 1970s did not have a class of wealthy, savvy, entrepreneurial merchants to create markets by organizing the means of production, commerce, and transportation. The Chinese government relied, instead, on government officials with desirable leadership characteristics: These were capable, business-minded administrators who helped create local, national, and international markets for local business by supporting village firms with low taxes and cheap land, attracting outside investment, advertising local products, negotiating business deals, and building distribution networks. Such a structure could have resulted in bureaucratic stagnation. But under Deng Xiaoping's system of merit-based selection and competition, any officials who were ineffective in finding ways to bring material wealth to local populations would lose their positions under fierce intra-national competition for economic success in the villages, townships, counties, cities, and provinces. This pragmatism effectively turned all levels of Chinese government officials, through the administrative networks initially established by Mao Zedong during his 30 years of communist central planning experiments, into a highly motivated "public merchant" class. These public merchants were China's market creators. ${ }^{1}$

With an enormously expanded and deepened market, China eventually set off its longawaited industrial revolution. Indeed, China's modern firms, regardless of their ownership type, operate according to the Smithian market-size principle to compete and meet the demand of well-developed and well-enriched domestic and international markets. Many of China's modern firms, while state-owned, have been highly productive, competitive, and profitable because they have the mass market to support their large-scale mass operations; comparable Chinese firms in the 1960s were highly unprofitable because they had no such markets or market mechanisms.

The objective of this article is to provide a brief summary and road map for Wen's (2016a) New Stage Theory (NST) of market creation and economic development, drawn from China's growth experiences and the economic history of the West. ${ }^{2} \mathrm{We}$ will describe the stages (and the sequence of those stages) of market creation and identify the sometimes easily overlooked steps that China's government took to successfully generate a full-fledged industrial revolution after 1978. This last point is critical: The Chinese central and local governments relied on China's state banking system and public land ownership to help create one of the largest unified manufactured goods markets in world economic history; this market nurtured, supported, and incentivized firm entry and industrial upgrading through the demand-side-driven adoption and market-oriented invention of modern manufacturing technologies and industrial organizational changes. Only toward the end of its second industrial revolution (which featured mass production of heavy industrial goods) did China begin to seriously engage in creating a financial market, pushing for the internationalization of its currency, and establishing market-based financial regulatory institutions to manage financial capital flows. China's prudent sequence of market creation explains the absence of any recurrent and destructive financial crises that have dominated the developmental history of the West and Latin America. China's sequential and "engineered" market-creation process thus offers a new model of 
economic development for developing countries. Behind the core economic validity of this market-creation strategy is an equally compelling reality: Political stability and social trust are the most fundamental pillars of the "free" market; forces that undermine stability and trust (such as premature and radical top-down political-economic reforms) can undermine the market itself. And it is worth noting here the distinction between the concept of an absolutely free market and the actual "free" markets in modern China, which are vibrant but directed by the government. This direction, or intervention, as noted throughout this article, is based on balancing the creative powers and the destructive powers of market forces.

\section{CHINA'S FAILED ATTEMPTS AT INDUSTRIALIZATION}

The thousands of years of China's history include technological innovations, cultural advances, and global voyages that have preempted or surpassed those of many nations. Yet, in the middle of the 20th century, China remained one of the poorest nations on earth, with one of the lowest standards of living and life expectancy and a per capita income just one-third of the average sub-Saharan African country. ${ }^{3}$

Of course, China did try to instigate economic growth — as well as increase military power to protect its national interests and encourage national pride, among other efforts. The economic reform in 1978 was certainly not China's first state-led attempt to industrialize. In fact, it was the fourth attempt since the Second Opium War.

After China was defeated by the British in the Second Opium War in 1860, the late Qing monarchy attempted to modernize its agrarian economy with the establishment of, among other things, a modern navy and an industrial infrastructure. The effort was a gigantic failure. The event that crystalized that failure was China's defeat in 1895 at the hands of the Japanese in the First Sino-Japanese War. As with earlier conflicts against the British, the war was a lopsided defeat. Despite China's hopes for true industrialization, even semi-industrialized Japan severely outmatched an underdeveloped China. Half a century passed, and by 1910 the nation was in turmoil, the Chinese government was deep in debt, and the hoped-for industrial base was nowhere in sight.

The Qing government's repeated failure to defend China against foreign aggression triggered demand for political reform. Social unrest ultimately led to the 1911 Xinhai Revolution that overthrew the Qing monarchy and established the Republic of China, the first "inclusive" government in Chinese history. This new republican government, based on a Western-style constitution, also tried to industrialize China by mimicking U.S. political institutions such as democracy and the separation of powers (that is, the checks and balances of the legislative, executive, and judicial branches of government). The Chinese people at that time adopted the slogans "Of the people, by the people, and for the people" and "Only science and democracy can save China." The educated elite revolutionaries believed that the Qing monarchy's failure to industrialize and China's overall backwardness was due to its lack of democracy, political inclusiveness, and pluralism - exactly as modern institutional theory has argued (again, see Acemoglu and Robinson, 2012). The political leaders of the republic established an inclusive form of government based on several premises: open access to political power (by including 
A Macro View of Industrial Revolution

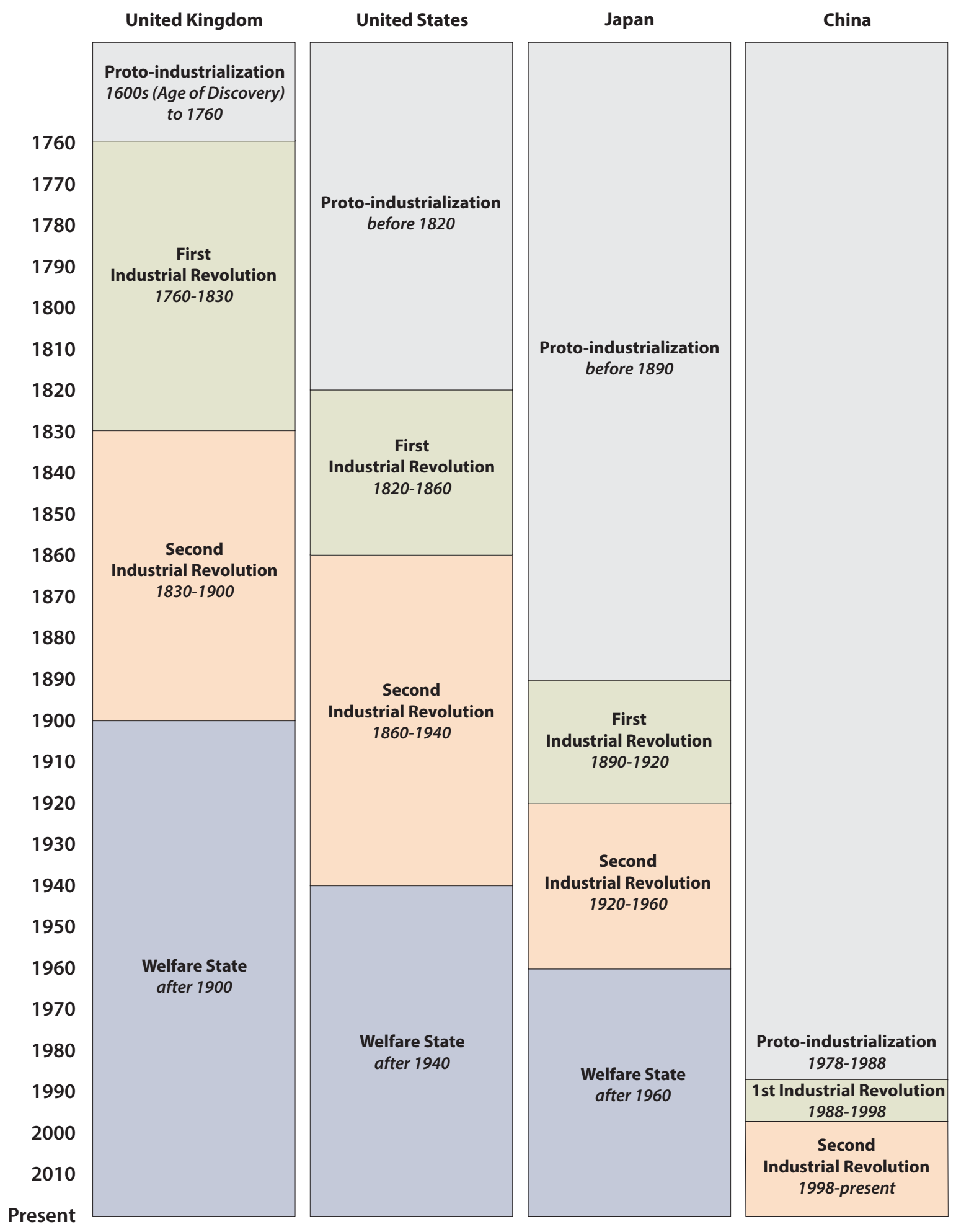

SOURCE: Estévez-Abe (2008) and Wen (2016a,b) and the references therein. 


\section{Proto-industrialization}

This stage involves the rural production of the most basic goods.

In the United Kingdom, production was coordinated and financed by a class of wealthy merchants under the "putting out" system (see endnote 13). Japan gained from the political stability of the Edo period (1603-1868) and continued its protoindustrialization in the early Meiji period (1868-1890). In China, this and other stages made use of collectively (not privately) owned enterprises.

\section{First Industrial Revolution}

This stage involves the mass production of textiles, through the use of rudimentary systems such as wood-framed and waterpowered machinery, as well as imported technologies (notably in Japan).

In the United States, mass production of textiles was driven by water power, especially along New England's fast-moving rivers, such as the first cotton-spinning mill (Blackstone River, Pawtucket, RI) founded by Samuel Slater. China made progress in this stage in much the same way as the previous three nations did, becoming the largest producer and exporter of, among others, textiles, cotton, furniture, and toys.

\section{Second Industrial Revolution}

This stage is divided into two components: (i) a boom in the industrial trinity of energy, transportation, and locomotive power and (ii) the mass production of the means of mass production.

In the United Kingdom (as well as in nations to follow), coal was a major source of power used to produce, e.g., iron, steel, and chemicals; advances in transportation included "macadam" roads, railroads, and canals and the steam engine. The United States had a railroad surge from the 1820 s through the 1870 s and relied on steam power after the Civil War; the production of the means of mass production included automobiles, telecommunications, and mechanized agricultural systems.

Japan's second industrial revolution progressed into the Second World War and continued under Allied occupation (1945-1952). In China, key developments have included a major surge in the extraction and consumption of coal and production of steel, cement, machine tools, and infrastructure (e.g., 70,000 miles of highway, almost 50 percent more than the U.S. total).

\section{Welfare State}

This stage involves an expansion of political rights and social services.

Examples in the United Kingdom include the National Insurance Act in 1911 and universal suffrage in 1928. In the United States, examples include the civil rights movement in the 1960s and the Violence Against Women Act in 1994. Japan enacted a minimum wage in 1959 and their modern, current national health insurance system in 1961. China has not yet completed its second industrial revolution and has not yet entered the welfare state. 
even the Communist Party in the government), ${ }^{4}$ modern corporations and financial institutions, new private property laws, and new versions of public universities. These reforms encouraged free trade, welcomed foreign capital, and fully embraced the bourgeois ethic throughout China, especially in large commercial cities such as Shanghai. But 40 years passed and, in 1949, China remained one of the poorest nations on earth in terms of average living standard and life expectancy and literacy.

This second failed attempt at industrialization in China was illuminated, again, by Japan's almost effortless yet ruthless invasion and occupation of China in the late 1930s and early 1940s, including the Nanking Massacre. The republic government's ineffectiveness in solving the problem of China's poverty also made it vulnerable to revolt; the communist peasant army defeated the regime in 1949 with the support of millions of impoverished peasants. Mao declared that "the Chinese people have finally stood up!" and initiated a third ambitious attempt to industrialize China-this time by mimicking the Soviet Union's social planning model instead of the West's capitalism and democracy. Thirty years passed and this third attempt at industrialization failed again: In 1978, China remained essentially in the same "Malthusian" poverty trap with per capital income no different from what it was around the Second Opium War.

To be fair, each of these failed attempts made some progress, but not enough to set off an industrial revolution. For example, Mao's regime managed to establish a basic (though highly unprofitable) industrial base and national defense system, which relied heavily on government subsidies through heavy taxation on agriculture. Agricultural productivity did improve, with the exception of the "Great Leap Forward" period. Life expectancy increased from about 35 years in 1952 to 68 years in 1982, and infant mortality fell from about 300 deaths for every 1,000 live births in 1952 to 31 deaths in 1999; rates of infection and disease, such as malaria, as well as deaths from floods and drought, also fell precipitously (Cook and Dummer, 2004; Blumenthal and Hsiao, 2005). In addition, China's literacy rate reached 66 percent in the 1960s. However, these improvements immediately translated into an expanded population-from 600 million in 1950 to 1 billion in the late 1970s, leaving income per capita barely changed from 1949, when the communist regime assumed power. Despite their potential for success, these changes did not provide food security or an escape from the Malthusian poverty trap. But they did lead directly to Deng Xiaoping's successful economic reforms in $1978 .{ }^{5}$

\section{DENG XIAOPING'S PRAGMATIC APPROACH TO ECONOMIC SUCCESS}

"It does not matter if the cat is black or white as long as it catches the rat."

-Deng Xiaoping

Deng Xiaoping worked alongside Mao Zedong through the political, social, and economic strife from the 1950s through the 1970s, including the Great Leap Forward. Deng developed a reputation for inner strength and philosophical flexibility, and Mao once described him as "a needle inside a cotton ball" (Vogel, 2013, p. 26). Although Deng was a high-ranking official in the Communist Party of China, he did not always agree with the Party's rigid, ideological 
approaches to economic reform (and in fact was purged twice from the Party as a result of those disagreements). ${ }^{6}$ When Deng assumed power in the late 1970 s, he had much cautionary evidence to consider: three major failures at industrializing China over a period of 120 years, spanning three different political regimes.

\begin{abstract}
Some officials were bold enough to suggest that the real cause of the problems China was facing was Mao Zedong himself, but Deng believed that a single person should not be held responsible for the failures of the previous two decades... [I]n Deng's view the larger problem was the faulty system that had given rise to those mistakes. The effort to gain control of the political system down to the household had overreached, creating fear and lack of initiative. The effort to gain control of the economic system had also overreached, causing rigidities that stymied dynamism. How could China's leaders loosen things up while keeping the country stable? (Vogel, 2013, pp. 21-22)
\end{abstract}

Ultimately, Deng Xiaoping's pragmatic and patient reforms led to a sustainable industrial revolution in China and paved the way for continued economic growth.

After observing major political upheavals and miscalculations based on ideology, Deng established fundamental principles behind his approach to economic reform: No socialist economy can achieve sustainable growth without market elements; but no market economy can flourish and continue to prosper without state-led industrial policy, social order, and political stability, which, in China's case, would be established by a strong state government. Deng's reforms were enacted, modified, and supported by high-ranking central government officials and implemented by local-level officials in the counties and countryside. China would "cross the river by touching the stones" and "seek the truth from its own practice": That is, China would not adhere to a strictly dogmatic approach, but rather would embrace persistent pragmatism, step by step.

Ultimately, China's development since those reforms has been very much outside any typical or traditional strategy enacted to promote economic growth, such as those suggested by the "Washington consensus" and "shock therapy."7 Rather, industrialization in China emerged from a more pragmatic process of trial and error according to the sociopolitical conditions in China at the time. Chinese government officials might have embraced existing economic theories and conventional advice to guide them (as did governments in Africa, Latin America, Russia, and Eastern Europe in the 1980s and 1990s), but Deng Xiaoping's government would forgo that advice and forge its own path. To be sure, the path to development after 1978 was a bumpy one and the Chinese government made many mistakes; fortunately, none of them has been ruinous, although some did inflict unnecessary pain on the Chinese people. But in its process of trial and error, the Chinese government under Deng also made many correct decisions that turned out to be critical for setting off China's truly long-awaited industrial revolution.

\title{
Key Steps
}

China's industrialization can be characterized by the following key steps:

(i) Solve the food security problem. The Chinese government established basic food security through a primitive agricultural revolution based on small-scale farming 


\section{Wen and Fortier}

\section{China's Village Firms}

In China, among other countries, industrialization began with the village firm. In their most basic form, these rural smallscale operations allowed farmers to manufacture simple goods outside of the growing season, to supplement income. Village firms existed during China's Great Leap Forward (1958-1962), when millions of farmers were relocated to unproductive centrally planned firms that tried to meet only local demand. Failure and famine followed. After 1978, the collectively owned village firms, although managed by government officials, were free to choose what to produce based on market demand. They were also guided toward long-distance trade and international exports with supportive commercial and credit policies. These were Deng Xiaoping's innovations. And, because the market expanded, the number and size of village firms also expanded and commerce flourished.

The output of village firms grew, on average, 28 percent per year from 1978 to 2000, doubling every 3 years. Adjusted for inflation, growth was still 21 percent per year (twice as fast as China's real GDP growth), doubling every 3.7 years.

\section{Characteristics}

Rural

Led by local officials (often democratically elected) serving as entrepreneurs/merchants/CEOs

Collective ownership but also private decisionmaking responsive to market demand

Residual claims and profit sharing

Institutional constraints but also market incentives, including competition and profit opportunities

Governmental support in securing credit and commercial information, conducting negotiations, coordinating supply chains, smoothing inventories, etc.

\begin{tabular}{|c|c|c|c|}
\hline \multicolumn{4}{|c|}{ Progress, 1978-88 } \\
\hline & 1978 & 1988 & Increase \\
\hline Industrial gross output & 51.5 billion yuan ( $14 \%$ of GDP) & 702 billion yuan (46\% of GDP) & 13.5-fold \\
\hline Number of village firms & 1.5 million & 18.9 million & 12.5-fold \\
\hline $\begin{array}{c}\text { Workers' aggregate } \\
\text { wage income }\end{array}$ & 8.7 billion yuan & 96.3 billion yuan & 12-fold \\
\hline Total capital stock & 23 billion yuan & 210 billion yuan & 9 -fold \\
\hline Number of workers & 28 million & 95 million & 3 -fold \\
\hline $\begin{array}{l}\text { Workers as fraction of } \\
\text { total rural labor force }\end{array}$ & 9 percent & 23 percent & 2.5 -fold \\
\hline
\end{tabular}

SOURCE: Wen (2016a) and the references therein. For the original data, see Zhang and Zhang (2001 [in Chinese], Appendix Table 1). 
and collective ownership of land. Government officials encouraged commercialized farming and supplementary (sideline) work to generate additional income for farmers.

(ii) Start a primitive rural industrialization based on township-village enterprises. This stage was critical because it channeled local surplus labor in rural areas into simple industries; this process would ferment the mass market needed to support mass production that would emerge from China's forthcoming industrial revolution.

(iii) Initiate a true industrial revolution of mass production of light consumer and industrial goods based on obsolete or imported technologies, with a well-fermented domestic market from the previous stage of rural industrialization as well as an international market for these goods.

(iv) Engineer a boom in the "industrial trinity" of energy, motive power, and infrastructure (especially transportation) based on the savings accumulated from the rural industrialization and the first industrial revolution. This boom in the industrial trinity naturally initiates a second industrial revolution, featuring the mass production of the means of mass production and mass distribution: These means (goods or tools) include steel, cement, and other intermediate goods used in buildings, highways, and railroads and the machinery used in light industries. The industrial trinity is the flagship industry during the initial phase of a second industrial revolution and a linchpin between the first industrial revolution and the second industrial revolution. This initial phase of the second industrial revolution becomes feasible, affordable, and profitable because of the thick market (enormous market demand) for energy, motive power, and infrastructure created through the earlier development stages, especially the first industrial revolution stage. Also, a later phase of the second industrial revolution (featuring mainly the mass production of various types of machine tools) naturally follows because an industrial trinity boom broadens and deepens the market for heavy industrial goods and machinery created through the earlier stages and especially through the industrial trinity boom itself.

China is currently engaged in its second industrial revolution. Once China finishes that second industrial revolution, the entire system of industrial production will be complete, forming a positive feedback loop such that all essential goods and commodities can be mass produced, including the means of mass production and mass distribution itself. This system is also flexible enough to respond to changes in consumer demand, unlike the rigid centrally planned system set up by the Soviet Union during the Cold War era. In the economic development of the West, large financial markets were created in stage iv (as previously described) mainly to facilitate this heavy industrial revolution (e.g., during the age of steel and railways), which required large sums of both public and private debt and credit. China has only recently begun to seriously engage in creating a large financial market, now that it is in the middle of finishing its second industrial revolution. Once this process is complete and China has a modern financial market, it will be ready to enter the next stage, a welfare state, which Western economies have enjoyed since the middle of the 20th century-or at least the end of World 


\section{Wen and Fortier}

War II-after finishing their own second industrial revolutions. This welfare state includes economic welfare, such as a social safety net, and political welfare, such as universal suffrage.

Therefore, the key to successful economic development and avoidance of the so-called "middle income trap" is to eventually finish a second industrial revolution, to successfully forge the industrial feedback loop to make mass production and technology creation selfsustainable. However, the correct steps to achieve this do not lead through heavy industrial buildup and financial liberalization in the early stages of development, but instead follow a continuous, specifically sequential creation of markets to nurture and stimulate industrial upgrading over time. Attempting to leapfrog by skipping the earlier, primitive developmental stages and entering the welfare stage prematurely can lead to development disorders, debt crises, and political chaos.

\section{APPLYING THE NEW STAGE THEORY OF DEVELOPMENT TO EACH STEP OF CHINA'S INDUSTRIALIZATION}

China's path to industrialization, as it turned out, mimics the sequence of the original Industrial Revolution, which occurred in Great Britain from the 18th to the late 19th centuries. In fact, Wen (2016a) argues that almost all successfully industrialized nations-such as northwestern European nations, the United States, and Japan-have followed a similar bottom-up and sequential approach to industrialization despite dramatic differences in their political systems. Many nations (including China in its earlier three failed attempts) have failed to kickstart their industrial revolution or have gotten stuck in the middle of their industrialization process because they have taken a top-down approach by skipping important earlier stages in the sequence of the original industrial revolution. With this top-down approach, the governments in developing nations build up advanced industries and systems during the very early stages of industrialization: capital-intensive industries such as those for chemicals, steel, and automobiles; modern financial systems such as a floating exchange rate, free international capital flows, and fully fledged privatization of state-owned properties and natural resources; and modern political institutions such as democracy and universal suffrage.

This top-down approach fails for a simple reason. A mass market is required to make mass production profitable and sustainable. Yet, it is extremely costly to create a mass market, especially one for heavy industrial goods, because the mass market requires not only political stability and enormous social trust but also a system of mass distribution. Developing countries simply do not have such a mass-distribution system and the purchasing power to support the mass production of heavy industrial goods. Again, a direct consequence of such top-down approaches is political instability and unbearable financial burdens.

Hence, an industrial revolution requires the correct procedure and the correct sequence of steps to create mass markets to support mass production. Traditional development strategies such as import substitution industrialization (ISI), the Gerschenkronian (1962) heavyindustry-biased "big push," "shock therapy," and the structural adjustment program based on the Washington consensus have failed precisely because they have all ignored certain key ideas: (i) the Smithian principle that the division of labor is limited by the extent of the market, 
(ii) the enormous social costs of market creation (which requires powerful state capacity and a strong-willed "mercantilist" government), and (iii) the correct sequence of creating the mass market under correct industrial policies, as illustrated below. ${ }^{8}$

\section{Step 1: China's Primitive Agricultural Revolution}

Throughout history, many nations have experienced pervasive market failures in agriculture, despite highly secured private land ownership and institutions that protect alienable land contracts. Even the governments of the Qing Dynasty and the Republic of China protected private property and contracts. But, as development economist Joe Studwell (2013) notes, in such a market-failure equilibrium, although land is privately owned with alienable contracts, powerful Darwinian forces eventually concentrate land in the hands of a few landlords and the majority of the population become tenants. ${ }^{9}$ The population grows, land becomes increasingly scarce over time, and landlords can then easily lease out plots at higher and higher rents. Landlords also act as money lenders and are able to impose high interest rates (usury). Within such an equilibrium, tenants have no incentives to make the investments to improve land productivity (e.g., through fertilizers or irrigation systems) because they have little security in maintaining access to that land and must face stiff rents and carry expensive debts. Landlords also have no incentives to invest in fertilizer and irrigation systems because they profit easily from merely collecting rent and lending at high rates. When tenant debts are not paid, landlords reclaim the plots of land along with collateral and then lease them out to other tenants. Nations in such an equilibrium of low agricultural productivity cannot withstand even minor natural shocks, such as drought or flood, and thus are constantly in a state of chronic famine. Évariste Régis Huc (1813-60), a French missionary Catholic priest who traveled through China from 1839 to 1851, bears witness to such conditions in his book A Journey through the Chinese Empire:

$[\mathrm{U}]$ nquestionably there can be found in no other country such a depth of disastrous poverty as in the Celestial Empire. Not a year passes in which a terrific number of persons do not $\mathrm{p}[\mathrm{e}]$ rish of famine in some part or other of China; and the multitude of those who live merely from day to day is incalculable. Let a drought, a flood, or any accident whatever occur to injure the harvest in a single province, and two thirds of the population are immediately reduced to starvation. You see them forming up into numerous bands-perfect armies of beggars - and proceeding together, men, women, and children, to seek some little nourishment in the towns and villages... Many faint by the wayside and die before they can reach the place where they had hoped to find help... (Quoted by Landes, The Wealth and Poverty of Nations, 1999, p. 346)

The 1911 Xinhai Revolution, as profound as it may be in modern Chinese history in moving toward a democratic political system, did not change China's miserable rural landscape. The revolution introduced pluralist political structures and inherited private land ownership from the Qing Dynasty. R.H. Tawney, the British economic historian who visited China in the late 1920s (10 years after the Xinhai Revolution and more than 70 years after Évariste Régis Huc), wrote about the devastating situation of Chinese peasant farmers: "There are districts in which the position of the rural population is that of a man standing permanently up to the neck in water, so that even a ripple is sufficient to drown him... in Shanxi province 


\section{Wen and Fortier}

at the beginning of 1931, three million persons had died of hunger in the last few years, and the misery had been such that 400,000 women and children had changed hands by sale" (in Studwell, 2013, p. 17).

The American sociologist and writer William Hinton, who conducted research in China's Shanxi province in the 1940s, also wrote about "the mundane realities of death by starvation during the annual 'spring hunger' when food reserves ran out, and of the slavery (mostly of girls), landlord violence, domestic violence, usury, endemic mafia-style secret societies and other assorted brutalities that characterized everyday life" (in Studwell, 2013, p. 18).

As dramatic as this may sound, many pre-industrial agrarian societies face these hardships. In China, they served as the socioeconomic foundation for the rise of communism and radical land reform led by Mao Zedong's communist party. Ironically, after the nationalist government was defeated by the communist army and fled to Taiwan, they conducted essentially the same type of land reform as the communists did in the mainland by taking the available land from landlords and dividing it up and distributing it equally among the farming population. Such a land reform triggered Taiwan's economic takeoff and industrial revolution.

However, Mao Zedong's plan to boost agricultural productivity after land reform by reorganizing individual farming units into large collectives was a dramatic failure. Agricultural production (with both traditional and modern techniques) requires special attention and is not easily or quickly converted to a system that might function well for other industries.

Historically, individual family farms have been fairly self-contained and have required few contributions from individuals outside the family. But during the Great Leap Forward, each farming collective assembled hundreds or even thousands of farmers within a militaristic organizational structure. In agriculture, the rate of return gained from this sort of division of tasks, specialization, and coordination among a large labor force is low and extremely limitedunlike the pin factory visited by Adam Smith, or the labor-intensive mass-production textile factories in late 19th century England, or the Ford automobile assembly lines in early 20th century United States. Growing crops is governed entirely by the natural biological cycle of plants, cannot be arbitrarily divided into many intermediate stages or intermediate goods, and is land intensive and nature sensitive. Hence, it is subject to rapidly diminishing returns from an increased supply of labor or a large-scale organization of labor. Moreover, because of the natural lack of complementarity among individual farmers' efforts in agricultural production, free-rider moral-hazard problems can easily arise in large organized farms that are based on teamwork.

Even in the development history of Western industrial countries, agriculture has always been the last sector to be industrialized or to achieve the economies of scale associated with the use of heavy machinery. For example, fully fledged mechanized farming did not take place in the United States until the 1940s, compared with the mechanization of the textile industry, which took place in the mid-1800s.

This premise holds true across different forms of ownership and property rights associated with land and the farm. Although a free market system would have likely avoided the Great Leap Forward and the malfunctioning of the communes within Mao's centrally planned collective farming, by no means does that imply that a free market would have automatically 
solved China's food security problems and set off China's agricultural revolution and then its industrial revolution. The Qing Dynasty's free markets did not bring about these events. And neither did the Republic era's free markets under political democracy. So why would they do so in the 1950s or the 1980s? Ultimately, agriculture would flourish in China. But China would first need to take a few critical steps for that to happen.

Deng's 1978 reform started with tearing down the large farming collectives and reverting to the traditional family-based farming units. This turned out to be the correct step to raise agricultural productivity. But this change meant returning to the simpler modes of production that were in use before communism, as in the Qing Dynasty (before 1911) and the Republic era (1912-1949). But this system of agricultural production was not sufficient for and did not lead to agricultural self-sufficiency and food security. As noted, private property rights were not the easy answer: The Qing Dynasty and the Republic era had those rights but did not make any significant progress in agricultural stability and food security.

For Deng's policies to be successful, they had to address other fundamental obstacles: (i) Peasant farmers lacked residual claim rights in the so-called "market determined" contracts that existed in Chinese history between land owners and those farmers. In other words, the farmers would not share in any profits and thus had no incentive to innovate or increase production beyond the bare minimum expected of them. (ii) There was no network of villagelevel irrigation systems or public roads connecting the villages and townships. Isolated farmers risked starvation - in the face of droughts, floods, or other natural disasters - if they moved from subsistence farming to some kind of agricultural specialization or commercialized farming aimed at long-distance trade, where they would need to sell their surplus of specific goods to buy other, necessary goods. (iii) The market was not large or stable enough to support commercialized farming and agricultural product specialization. And (iv) no rural industrialization had taken place to absorb the surplus labor in the countryside and dramatically raise farmers' productivity through manufacturing.

Mao's government had actually solved two of these problems during the Great Leap Forward and afterward (mostly during the government-engineered "rural corporative movement"): It had built up the infrastructure of public irrigation systems and local roads to accommodate the collective farms. This infrastructure provided the necessary improvements in technology and transportation during Deng's agricultural reform era to help increase the productivity of family-based agricultural efforts and the profitability in agricultural trade. Another easily overlooked but critical accomplishment is the establishment of rural factories (eventually known as township-village enterprises after being called communal factories during Mao's era) based on the cooperative spirit that Mao helped to create among Chinese peasant farmers in the vast rural areas. This "social capital" - a pillar of the "free" market-turned out to be a crucial factor for detonating China's rural industrialization after Deng's 1978 economic reform. ${ }^{10}$

It is worth considering Adam Smith's perspective on Scotland's economic environment in the 18th century:

In the lone houses and very small villages which are scattered about in so desert a country as the highlands of Scotland, every farmer must be butcher, baker, and brewer, for his own 
family. In such situations we can scarce expect to find even a smith, a carpenter, or a mason, within less than twenty miles of another of the same trade. The scattered families that live at eight or ten miles distance from the nearest of them, must learn to perform themselves a great number of little pieces of work, for which, in more populous countries, they would call in the assistance of those workmen.... There could be little or no commerce of any kind between the distant parts of the world. What goods could bear the expense of land-carriage between London and Calcutta? Or if there were any so precious as to be able to support this expense, with what safety could they be transported through the territories of so many barbarous nations? (The Wealth of Nations, Chapter III)

Mao's public land ownership and rural corporative movement transformed similarly isolated Chinese farms and villages, challenged by the same limited options as those described by Adam Smith, into rural corporations. These corporations were not profitable because of the limitations of the market. It was Deng's series of reforms that extended a unified national market for rural corporations leveraging those rural infrastructures built by Mao's government and the social trust among the farmers nurtured by the movement and ethic (including the Great Leap Forward) of the commune.

Deng's reforms also provided solutions to other obstacles that Mao's communist regime could not solve: Farmers were given the incentives to work harder than before because their compensation was now linked to their individual efforts-again, despite public ownership of the land. Farmers were given a 15- or 30-year lease to work the land and the freedom to decide what crops to grow (based on market demand and other factors) and when and how long to work. The productivity of land varies greatly, depending on the type of soil and the crops planted. Deng's system of public ownership with private decisionmaking allowed farmers the independence to choose how to maximize their output, for example, by diversifying their crops, targeting crops most suitable for the soil, and being able to respond to market demand.

More importantly, under Deng's new incentive mechanism, farmers became the residual claimers on the output they produced, after meeting government quotas. Hence, farmers worked harder and longer hours and could fully use evenings and seasonal leisure time as they desired. All these factors combined to form an environment that produced an unprecedented boom in agricultural productivity in China soon after 1978.

As a result of this primitive agricultural revolution, China's aggregate agricultural output increased significantly and steadily. For example, crop output rose permanently by more than 20 percent in 1980 alone (see Wen, 2016a). Now, this permanent increase in agricultural output could have been used as surplus, as has been the case throughout history, to support additional children in the family, which in China would have amounted to millions of new babies. But China's Malthusian trap did not continue and the multitude of additional children did not come. The main reason is China's infamous one-child policy implemented in 1979 by the central government. Another reason is that a different sort of revolution-a rural industrialization-was taking place. This early, limited industrialization began to offer an increasing variety of goods to consume. And suddenly the populace had a choice: work harder and use the surplus to consume more goods or use it to raise children. Essentially, they chose the former. 


\section{Step 2: China's Proto-industrialization}

A well-known and well-documented phenomenon soon after the 1978 reform was the emergence of the so-called township-village enterprises across China's vast countryside. These collectively owned enterprises flourished because (i) farmers were eager to find new sources of income beyond what their subsistence-level farming offered and (ii) local village and township governments also wanted (and in fact were required by the central government) to rapidly develop their local economies to improve the conditions of the local population. But although the existence of these township-village enterprises is well studied, their relation to Western economic history and the Industrial Revolution is not. These enterprises were, in fact, the key to triggering China's industrial revolution. And, although these enterprises may seem highly specific to China alone, this form of rural industrialization is in fact reminiscent of the primitive (proto) industrialization that flourished in 17th and 18th century Great Britain over the two hundred years or so before the British Industrial Revolution. ${ }^{11}$

Affluence in industrial societies often means the ability to mass-produce manufactured goods, such as processed food and textiles and shelter and means of transportation. In an agrarian society, before machinery and other forms of capital are invented or used in production and can be mass-produced, labor is the most important and perhaps the only means of producing manufactured goods. (Of course, human labor produces these goods with the help of primitive tools.) But the majority of the members of the labor force do not engage in manufacturing; instead, they reside in the countryside and devote themselves to agricultural production to maintain food security.

Between the 17th century and the middle of the 18th century in Great Britain, more and more peasant families were engaging in small-scale manufacturing and choosing to specialize in textiles and other products as the market deepened. More and more rural households were transformed into commerce-based proto-industries involving specialization and long-distance trade. Over a century and a half, the market fermented and organizational developments took hold; these part-time manufacturing workers and village firms eventually transformed into full-time workers and large-scale factories. Mass production became the critical means for merchants and other capitalists to compete for domestic and international market shares.

Such a proto-industrialization was necessary for detonating the British Industrial Revolution because mass-production-based industrialization requires a large and deep market to make the division of labor and large-scale cooperative efforts profitable. Industrialization also relies on sufficiently high incomes (wages) and the purchasing power of the grassroots population, which in turn requires that a large pool of the autarkic peasants move away from subsistence farming and engage in cooperative manufacturing within a framework of industrial organization. And all this must be accomplished without jeopardizing food security. In addition, factories are erected on land, and both land and labor are cheaper and more readily available in rural areas than in urban areas. For one thing, providing board and housing for peasant workers in the cities would be extremely costly. ${ }^{12}$ Hence, using local land and local surplus labor in the rural areas to produce manufactured goods for long-distance trade is the most economical way of starting a proto-industrialization, regardless of who owns the property, as long as (i) the right to make decisions resides in the firms and (ii) business-failure 


\section{Wen and Fortier}

risks are borne by these rural industries. It is precisely this proto-industrialization that is needed to create the mass market and mass distribution networks to support a genuine first industrial revolution based on labor-intensive mass production.

There is one fundamental difference between the origination of China's proto-industrialization and the origination of Great Britain's proto-industrialization: In Great Britain (and other parts of Europe), it was mainly the merchants that took the initiative to finance and organize the village industries: They engaged and recruited the peasants to work cooperatively; they coordinated the production systems and cartage in the manufacturing of light consumer goods (mostly textiles); they took charge of long-distance trade and sales and provided the needed trade credit and raw materials for continuous production (e.g., from the emergence of the rudimentary "putting-out" system of local production all the way to the emergence of large factories in rural areas). ${ }^{13}$ So, in many parts of Europe, the catalysts (or "economic enzymes," if you will) of market creation and rural industrial organization were the merchants, not the owners of the production factors (labor, land, and tools). ${ }^{14}$ What motivated and financed the merchant class's proto-industrial activities through the putting-out system was the enormous world market and profit opportunities created by the mercantilist governments of Europe in general and Great Britain specifically and their trade policies based on colonialism, imperialism, and the slave trade. ${ }^{15}$

In China, however, that entrepreneurial role of domestic and global market creation and rural production-organization was played essentially by the central government acting in concert with the local village-level and township-level governments. These government officials were key agents in facilitating the organization of the factors and methods of production.

As Adam Smith observed, in a primitive agrarian society, the family is the basic unit of production and exchange. The family members produce everything they need. They might have the incentive to specialize and produce more than what is needed, through the division of labor, and sell that surplus to other families. But, because of the lack of an organized market, it is risky to specialize in producing one type of household good and to depend on other sources for other necessary goods. Clearly, food security is the highest priority, and the lack of any "insurance" for failed sales in the market is daunting. Yet the division of labor and separation of demand and supply through social specialization is the key to improving labor productivity. Even the most primitive form of rural factories requires peasants from different families to be organized into teams (essentially, a corporation) to engage in coordinated production and to share the profits and business risks. Such an organization requires initial capital (more than a hundred or thousand times a farmer's annual family income) as well as fundamental trust among the workers and the organizers. Moreover, success depends critically on efficient long-distance distribution channels to ensure sales and supply of raw materials (which may not be available locally, such as cotton and wool).

As noted earlier, a new and powerful merchant class emerged in the 16th to 18th centuries in Europe; they were backed by mercantilist and militarized state support and motivated by enormous monopoly profits from global trade (based on colonialism, imperialism, and the slave trade). ${ }^{16}$ These merchants created markets and served as the organizers of protoindustries, which paved the way for the British Industrial Revolution-which hinged on 


\section{Banking and Finance}

Throughout China's industrial revolution, all of its banks have been state owned. Although those banks continue to be state owned today, the Chinese government restructured and reformed its banking industry in the late 1970s and early 1980s.

The People's Bank of China, which was China's sole bank during Mao's regime, engaged in both commercial and central banking; in 1984, it became China's central bank exclusively. The four major state-owned banks that provide banking services are listed here, along with the year they were restructured:

- Bank of China (1979)

- Agricultural Bank of China (1979)

- China Construction Bank (1981)

- Industrial \& Commercial Bank of China (1984)

These major state-owned banks have been responsible mainly for financing China's large state-owned enterprises. These major banks did not provide loans to China's small village firms in the early stages of industrialization, despite the strong profit motives of those village firms. Initially, risk and distance prevented these banking relationships. How, then, did village firms raise the funds to purchase materials, secure equipment, and pay salaries?

Initially, village firms were "self-financed" in the 1980s and 1990s by two complementary methods: pooling farmers' somewhat meager savings and direct loans from local, collectively owned credit unions. As Lu (2006) states, "smaller commercial banks and many nonbank deposit institutions... organized on a shareholding basis...serve[d] local needs." Most of these firms also relied on trade credits to finance working capital.

Market-oriented reform of the banking industry emerged from the October 1992 national congress, when the Communist Party leadership agreed to establish the "socialist market economic system."

This decision immediately accelerated reforms on all fronts, including the banking and financial sector. The promulgation of a central bank law and a commercial bank law in 1995 marked a watershed between a centrally planned "monobank" system and a post-reform modern central banking system based on fractional reserves. (Lu, 2006, p. 6)

Since then, during China's second industrial revolution, many private firms have invested in new technologies that have been partially financed by China's major state banks and partially self-financed through these firms' retained cash flows.

China's entry into the World Trade Organization (WTO) in 2001 imposed requirements for additional reform of its financial sector, including allowing entry to foreign financial firms. That process, which has included measures taken to prepare its domestic banks to compete, is ongoing. By October 2005, for example, 138 foreign banks were approved to conduct yuan-based banking services, with assets amounting to $\$ 84.5$ billion, equivalent to 2 percent of total assets in China's domestic banking sector at the time.

SOURCE: Lu (2006) and Wen (2016a) and the references therein. Also see Lu for a description of the "inherited links" between China's large state-owned enterprises and large state-owned banks.

Britain's monopoly power and hegemony in the global textile market and cotton trade. Such a powerful merchant class was obviously lacking in 1978 China, and thus China was stymied by a missing-market-creators problem. So, how would China ignite its proto-industrial revolution almost as soon as the reform started in 1978?

Deng's government imposed a national ideology: economic development through all possible means conditioned on political stability and social order. Government officials were expected to find ways to bring material wealth to local people. Fierce competition for economic success in both rural and urban areas effectively turned all levels of Chinese government officials into a highly motivated "public merchant" class. Through merit-based selection and competition with neighboring areas, there emerged a new generation of very capable business-minded administrators who helped create local, national, and international markets for local business by supporting village firms with low taxes and cheap land, attracting outside investment, advertising local products, negotiating business deals, and building distribution networks. 
These market creators did not bear the stigma of traditional merchants; they were not seen by the Chinese populace as profiteers, traders, arbitragers, and opportunistic salesmen. They reinvented and revolutionized the historical European merchant-based putting-out system within China, except on a much larger scale and with an overtly nationalistic mission: They provided critical entrepreneurial and managerial services to village firms by acting as CEOs and members of "boards of directors" (à la Jean Oi, 1992), providing credit through China's state banking system, enforcing payments, supplying commercial information, organizing industrial parks and trade exhibition forums, and negotiating with out-of-region entities for the supply of raw materials and intermediate goods needed for production. These officials also sometimes even coordinated the absorption of inventories and the smoothing of supply and demand shocks to firms. They also helped organize farmers in their spare time to build roads, improve irrigation systems, or obtain loans from provincial or national banks to build local infrastructure. According to Oi (1992), "The impressive growth of collective rural industrial output between 1978 and 1988 is in large measure a result of local government entrepreneurship. Fiscal reform has assigned local governments property rights over increased income and has created strong incentives for local officials to pursue local economic development. In the process, local governments have taken on many characteristics of a business corporation, with officials acting as the equivalent of a board of directors." 17

Hence, this "Chinese style" rural industrialization occurred through the emergence of a large number of collectively owned village firms. This process immediately ended China's shortage economy caused by the central planning of Mao's era. In less than 5 years after the 1978 reform, China had successfully ended all rationing imposed on food (including meat), textiles, and other light consumer products.

Another critical distinction in China's path to industrialization was its unprecedented pace and scale, compared with more than 200 years of proto-industrialization that occurred in 16th to late 18th century Europe. In merely a 10-year period after Deng's reforms began, between 1978 and 1988, the number of village firms, their industrial gross output, and farmers' aggregate wage income all increased more than 10-fold. Employment tripled. China's explosive growth continued throughout the 1990s and 2000s in a type of chain reaction in which expansion led to more expansion and growth led to more growth. By 2000, the number of workers in village firms had reached more than 128 million (not including the migrant workers in the cities), accounting for a remarkable 30 percent of China's entire rural labor force. Village industrial gross output reached 11.6 trillion yuan, a 16.5-fold increase compared with its 1988 value or a 225-fold increase compared with its 1978 value; its average rate of growth was 28 percent per year between 1978 and 2000, doubling every 3 years, and the total increase in real gross output of village industries was at least 66 -fold over the $1978-2000$ period. ${ }^{18}$ This scale and speed of long-lasting economic growth is unique in economic history.

Again, this stage of China's industrial revolution replicates a comparable stage during the British Industrial Revolution, which also started in the countryside. In China's case, tens of millions of village enterprises arose in the vastly impoverished rural areas in the late 1970s and early 1980s. These village firms were organized and managed by the uneducated peasants who were not much different from their Qing dynasty ancestors in the 17th and 18th centuries. 
Some economic historians and the human-capital school of development attribute China's failure to attain industrialization at that time to the lack of education among these peasant farmers. But in fact it was equally uneducated peasant farmers who brought China's industrial revolution to fruition in the late 20 th century. ${ }^{19}$

So, the puzzle is no longer why a proto-industrialization was suddenly kick-started in China after 1978, but rather why it did not happen earlier in Chinese history, despite private property rights, such as those during its first and second attempts of industrialization in the 19th and early 20th centuries.

The answer to this puzzle is now much clearer: In the Qing Dynasty and the Republic era, China did not have a well-fermented unified domestic or global market to support the division of labor and it did not have a large number of market creators and rural-firm organizers. During these early attempts at industrialization, the absence of markets and marketcreators could have been remedied only by some kind of intervention. As noted, previous industrializations were led by a powerful class of merchants supported by a strong-willed and militarily powerful pro-commerce and pro-manufacturing mercantilist government and motivated by monopoly profits in the world market through, for example, armed trade and colonialism. ${ }^{20}$

\section{Step 3: China's First Industrial Revolution}

"It is not worth my while to manufacture your engine for three counties only, but I find it very well worth my while to make it for all the world."

-English manufacturer Matthew Boulton (1728-1809), to his business partner James Watt (1736-1819), cited by Eric Roll, [1930], 1968, p. 14)

What good would it do to adopt the division of labor in Adam Smith's pin factory if the market demand were only one pin per day instead of 40,000 per day? Governments in developing countries are often eager to modernize their economies by adopting the latest, mostefficient mass-production technologies: Why bother to use slower, outdated technologies when faster, more-productive technologies are available? But without finishing a protoindustrialization and engaging in a first industrial revolution, such a process is doomed from the start. The relationship between mass production and the size of the market is key.

After a decade of rapidly building up proto-industries and commercial networks, unifying its domestic market, and expanding that market through international trade, China reached the tipping point of its first industrial revolution in the late 1980s. The flagship industry of China's first industrial revolution was textiles and clothing.

China's primitive agricultural revolution allowed for some economic gains among the rural population, and the commerce associated with the proto-industrialization rapidly improved the living standard and purchasing power of that population. Hence, local demand for textiles and apparel continued to rise throughout the 1980s, owing to the income elasticity of these goods. Fueled by this rising demand as well as intense competition among small firms, mass production of textiles and garments became profitable. As a result, China's total production of yarn and cotton fabrics increased from 330,000 tons and 1.9 billion meters in 1985 to 
8.5 million tons and 32.2 billion meters in 2002, with a 23 -fold increase for yarn and a 15 -fold increase for cotton fabrics over 17 years (the implied annual growth rate is 20 percent and 17 percent, respectively). Total garment output increased from 1.3 billion pieces in 1985 to 9.5 billion pieces in 1996, with an average growth rate of 22 percent per year. Total chemical fabric production increased from 94.8 thousand tons in 1986 to 991.2 thousand tons in 2002, growing by 16 percent per year on average. As early as 1990, there were already tens of millions of spindles in the east and south of China with well-formed industrial production chains and textile manufacturing clusters. By 1994-95 (more than 6 years before joining the World Trade Organization [WTO]), the number of spindles reached 40 million, one for every 25 people in China.

This growth was driven initially by the large state-owned textile enterprises (which gradually became profitable during the proto-industrialization) because of their scale of operations and easy access to finance, but then was dominated primarily by privately owned enterprises as soon as they caught up with the mass-production technologies through self-financed investment. The profits of these privately owned enterprises grew by 23.5 percent per year between 1990 and 1997.

As a result, the textile and clothing industry became the largest manufacturing industry and major source of foreign exchange in China during its first industrial revolution, between 1988 and 1998. This industry included about 24,000 enterprises and employed about 8 million workers even in the early 1990s; its exports accounted for more than 20 percent of China's total exports. China surpassed the United States and became the world's largest producer and exporter of textiles and clothing in 1995, six to seven years before joining the WTO, and has retained this dominant position ever since (see Wen, 2016a). ${ }^{21}$

Again, the Chinese government played a pivotal role in each of the stages of China's industrialization and certainly did so in this textile-led first industrial revolution. China's government in 1979 chose to implement additional economic reforms and policies to target the nation's textile and clothing industry, which early on was one of the primary industries it promoted. Previous attempts at industrialization, as under Mao's regime, focused on promoting heavy industries such as steel. The Chinese government under Deng promoted the textile and clothing industry for three key reasons: (i) This industry was consistent with China's comparative advantage in its abundance in labor, (ii) it did not require advanced technologies and had relatively low entry costs, and (iii) the domestic and international markets for these products were huge.

To promote the textile industry, the government launched a policy called "Six Priorities," which favored the textile industry in six areas: supply of raw materials, energy and power, bank loans, foreign exchange, imported advanced technology, and transportation (see, e.g., Qiu, 2005). The Chinese government was directly involved in the import and storage of cotton nationwide to smooth domestic cotton prices and demand. Moreover, it established sophisticated organizations to nurture this industry. The following government agencies were created (long before China joined the WTO) to supervise, regulate, and assist the textile and clothing industry in coping with international textile market rules and competition, each with specific functions and areas of focus. 
- China Chamber of Commerce for Import and Export of Textiles

- China National Textile Industry Council

- China Petroleum and Chemical Industry Association

- Ministry of Agriculture

- Ministry of Commerce

- National Development and Reform Commission

- State Administration for Quality, Supervision, Inspection, and Quarantine

- State Environmental Protection Administration

- State-owned Assets Supervision and Administration Commission

- Textile Industry Standardization Institute

Raw Material Supply. The Ministry of Agriculture is responsible for key raw material industries including cotton, silk, and wool. The National Development and Reform Commission (NDRC) is responsible for the importation of raw materials, for which import quotas still apply.

Production and Processing. China National Textile Industry Council (CNTIC) guides the production and processing in the textile industry. CNTIC is the legacy agency of the nowdefunct Ministry of Textile Industry. Its broad responsibilities include the implementation of industrial development guidelines for the sector.

Export Quota License. The NDRC's Department of Industry supervises the national textile industry. The Bureau of Economic Operation is responsible for formulating policies and controlling the export quota licensing system in the textile industry. However, the Ministry of Commerce is responsible for actually issuing export quota licenses.

Standards-Setting. The State Administration for Quality, Supervision, Inspection, and Quarantine (AQSIQ) is the government agency responsible for setting technical, safety, and environmental protection standards for textile products in China. In the textile sector, AQSIQ functions as a standards-setting coordinator. When setting standards, it seeks technical support from the Textile Industry Standardization Institute (TISI) and consults with the CNTIC. AQSIQ is also the agency responsible for enforcing standards and providing certification of products and enterprises. AQSIQ is also involved in drafting laws and regulations governing industrial standardization in the textile sector.

The textile industry was instrumental in China's first industrial revolution and led the way to China's second industrial revolution in the late 1990s; this progression strongly resembles the pattern of the British Industrial Revolution and hence sheds considerable light on the long-standing puzzle and internal logic of an industrial revolution in general.

The textile industry was also the flagship industry during the first industrial revolution in Great Britain. From the 1760s to the 1830s, a series of inventions of simple yet powerful wood-framed tools and machines rapidly sped up spinning and weaving. However, the British Industrial Revolution was not driven merely by these technological inventions, per se, as the conventional wisdom often assumes. Rather, it was driven mainly by the colossal textile market created by British merchants and the government and was the outcome of fierce competition among the European proto-industrial textile firms for market share. 
Textile production is much easier to mechanize with simple low-cost tools than growing crops and building shelters; it is also much easier to divide this type of production into many intermediate stages in an environment of division of labor. Textile production is simple enough that even young or otherwise unskilled workers can easily accomplish it. It can involve longer working hours and thus can potentially absorb a huge amount of surplus labor from rural areas in which only agricultural work had been done.

The textile market is potentially the largest and most income-elastic, compared with other light consumer goods such as jewelry, pottery, or furniture; hence, the textile market has the potential for rapid growth as incomes rise and mass-production technology progresses. Moreover, the competition inherent in this market naturally stimulates innovation. ${ }^{22}$

Before the Industrial Revolution, Great Britain had nurtured its textile market for hundreds of years, at least since Elizabeth I (1558-1603) and possibly even earlier. These interventions created Europe's largest textile market and distribution network by the early 18 th century, and Great Britain eventually possessed the largest number of early textile firms. However, by the early and middle of the 18th century, after centuries of proto-industrialization and the boom in textile production across Europe, the woolen and linen textile markets for British textile products (based on artisan workshops) appeared virtually saturated. Yet the demand for cotton textiles was growing rapidly while the supply (imports from India) was restricted by the British mercantilist laws to protect its domestic woolen textile market. This environment was immensely competitive. This competition was critical for stimulating technological innovation and discovery of new varieties of consumer products: To survive market competition, firms needed to adapt and gain new market shares. To nurture its textile industry, Great Britain would reshape the market, as exemplified by the government-promoted shift from the traditional woolen textiles to cotton textiles in the 1730s (e.g., as reflected in the Manchester Act in 1736), the shift from workshops to cotton mills in the 1740s, and the subsequent Industrial Revolution.

Hence, it is not surprising that the Industrial Revolution started first in Great Britain and first in this particular industry-because only a massive market with mature distribution networks and highly income-elastic demand could stimulate and sustain profitable mass production through mechanization. Interestingly, this economic logic has not changed since the British Industrial Revolution. Virtually all recently developed nations followed the same path paved by the British to successfully kick-start their own first industrial revolution. ${ }^{23}$

\section{Step 4: China's Industrial Trinity Boom and Second Industrial Revolution}

The industrial trinity is defined as three key industries: energy, motive power, and infrastructure. Infrastructure includes but is not limited to transportation and communication. The industrial trinity represents the flagship industries during the initial phase of a second industrial revolution.

China kick-started its massive buildup in energy and infrastructure only around the middle of the 1990s, after finishing or nearly finishing its first industrial revolution, because only then did such capital-intensive industrial projects become affordable and profitable.

The boom in the industrial trinity was triggered and supported by the market demand created by the first industrial revolution. Moreover, the boom itself generates colossal demand 


\section{Three Gorges Dam}

The Three Gorges Dam is located across the Yangtze River in the town of Sandouping, in the Yiling District of Yichang Prefecture in the province of Hubei. The dam is the world's largest power-production facility: As of 2014, it generated 98 terawatt-hours of electricity. The dam was built also to increase the shipping capacity of the river and reduce flooding downstream.

Damming the Yangtze River was long imagined and supported by Chinese leaders, including Sun Yat-sen, the founder of the Republic of China, and Mao Zedong, after the communist takeover. The National People's Congress, in 1992, approved the project and finally secured enough support and funding.

The dam was fully functional as of July 4, 2012. A ship lift was completed in December 2015. The estimate of full cost recovery is once 1,000 terawatt-hours of electricity is generated, which translates to a yield of 250 billion yuan.

\begin{tabular}{|c|c|}
\hline Preparation & $\begin{array}{l}\text { Moved } 102.6 \text { million cubic meters ( } 134.2 \text { million cubic yards) of earth and more than a million } \\
\text { residents }\end{array}$ \\
\hline Construction & 27.2 million cubic meters ( 35.6 million cubic yards) of concrete; 463,000 tons of steel \\
\hline Dam Size & 2,335 meters (7,661 feet) long; 185 meters (607 feet) above sea level \\
\hline \multirow{5}{*}{ Reservoir Size } & $\begin{array}{l}175 \text { meters ( } 574 \text { feet) above sea level (at its highest level); } 110 \text { meters ( } 361 \text { feet) higher than } \\
\text { the river level downstream }\end{array}$ \\
\hline & 660 kilometers ( 410 miles) long; 1.12 kilometers ( 3,700 feet) wide \\
\hline & 39.3 cubic kilometers $(31,900,000$ acre.feet) of water \\
\hline & 1,045 square kilometers (403 square miles) of total surface area \\
\hline & 632 square kilometers ( 244 square miles) of land flooded on completion \\
\hline \multirow[b]{2}{*}{ Total Cost } & 180 billion yuan (US\$22.5 billion) initially estimated \\
\hline & $\begin{array}{l}148.365 \text { billion yuan spent (US\$18.5 billion): } 64.613 \text { billion on construction, } 68.557 \text { billion on } \\
\text { relocating residents, and } 15.195 \text { billion on financing as of } 2008\end{array}$ \\
\hline
\end{tabular}

SOURCE: Mufson (1997), Jones and Freeman (2001), and Chinese National Committee on Large Dams (2010).

for heavy industrial goods and materials, which in turn provides economic forces and markets to support the second industrial revolution, which features mass production of the means of mass production and mass distribution (such as heavy intermediate goods, machinery, and infrastructure).

The second industrial revolution enables a society to provide a large and steady supply of machinery and various intermediate goods as well as means of mass distribution to sustain the continuation of the first industrial revolution. In other words, this environment calls for the mass production and provision of heavy industrial goods such as chemicals, cement, iron, steel, communication equipment, automotive products, ships, cars, trucks, airplanes, and a large organized credit system. Any new discoveries or inventions that facilitate the efficient supply of these goods will necessarily be adopted into the production process, as long as their benefits outweigh their costs. These innovations include new forms of energy, motive power, transportation, and communication and new (man-made) materials. Also, innovations in 


\section{High-Speed Rail}

"High-speed" rail refers to commercial railway train service that can achieve speeds of $200 \mathrm{~km} / \mathrm{h}$ (124 mph) or higher, the international standard. Commercial train service in China in 1993 averaged only $48 \mathrm{~km} / \mathrm{h}$ (30 mph) and was inadequate to satisfy increasing demand for transportation of passengers and cargo. The Chinese government attempted to modernize the railway system by, first, increasing the speed and capacity of existing lines through double-tracking, electrification, grade improvements, reduced turn curvature, and use of continu- ously welded rail. China's "Speed-Up” campaigns in April 1997, October 1998, October 2000, November 2001, and April 2004 upgraded passenger service on $7,700 \mathrm{~km}$ (4,800 miles) of existing track to just below the threshold of "high-speed": $160 \mathrm{~km} / \mathrm{h}$ (100 mph). Currently, China has the world's longest high-speed rail network: as of January 2016, over 19,000 km $(12,000$ miles) of track, which is more than the rest of the world's high-speed rail tracks combined. Plans are in place for a network of 30,000 km (19,000 miles) by 2020 .

SOURCE: Wen (2016a) and the references therein.

financial services and credit management and a stable and well-managed national banking system are needed to facilitate the large volume of trade.

Some examples: The construction of the world's largest hydroelectric power station, the Three Gorges Dam, began on December 14, 1994. Except for a ship lift that was completed in 2015, the dam project was completed and fully functional on July 4, 2012.

And the buildup of China's high-speed rail network started only in the late 1990s. Since the operation of China's first high-speed railroad in 2008, 28 Chinese provinces (out of 30) are now covered by the world largest and longest high-speed rail network (more than 19,000 kilometers in length and 50 percent greater than current world capacity outside China).

Vast improvements have been made during the past two decades in irrigation systems, sewage systems, street and highway networks, air and rail transportation, electrical grids, gas and oil pipelines, and so on. For example, the total length of public roads reached 4,230,000 kilometers (about 2,643,700 miles), including 111,950 kilometers (about 70,000 miles) of highways at the end of 2014, surpassing the U.S. system as the world's longest highway system. More than 95 percent of China's villages are now connected by asphalt roads. As a result, China now enjoys an exceptionally high ranking in the World Bank Logistics Performance Index (LPI). China is one of the few developing countries to achieve an LPI score comparable to that of high-income nations in international shipments, infrastructure, custom services, logistics competence, tracking and tracing, and timeliness, with an overall LPI score of 3.53 in 2014, ranked 28th in the world, next to Portugal but above richer countries such as Turkey, Poland, and Hungary. (See World Bank, 2014.) Moreover, China's infrastructure-construction boom is still continuing at an unprecedented speed both domestically and internationally. Such remarkable catching-up in infrastructure has no doubt fed-back and made a significant contribution to China's rapid market formation and prepared China well for the next decade of growth in industrialization. 


\section{OVERVIEW OF CHINA'S GOVERNMENT INVOLVEMENT AND PRIVATIZATION POLICIES}

The Chinese government has had a role in each of these stages of industrialization. Beyond the general expectations for providing social order and political stability, China's government worked to overcome the problems of missing markets and market-coordination failures during each of the stages described here. In addition, the government plays another critical role: Industries generate enormous positive externalities for the national economic system that only the state can fully internalize-especially in the areas of energy, motive power, financial services, and infrastructure, which are pivotal for overall development and national security. ${ }^{24}$ China's second industrial revolution, starting in the mid-1990s, benefited tremendously from the large-scale state-owned heavy industries and scientific research institutions established during Mao's era. ${ }^{25}$ These heavy industries and research institutions had been highly inefficient and unprofitable and were large financial burdens for China. But they did not remain so. Once China finished its proto-industrialization and its first industrial revolution, it adopted a competitive, profit-driven approach to managing heavy industries and a merit-based reward system for research and innovation. ${ }^{26}$

The Chinese government (wisely, as it turns out) chose to retain its "inefficient" stateowned heavy industries in the 1980s and early 1990s instead of dismantling them through marketization and privatization, which is what Russia did during its initial "shock therapy" reforms in early 1990s. China maintained many important state-owned enterprises and postponed their reform until the late 1990s, after China finished both its proto-industrialization and its first industrial revolution. ${ }^{27}$ By the late 1990s, China had become the world's largest market for modern infrastructures and heavy industrial goods. Only a market as large as this would be able to profitably sustain large state-owned heavy industries. Hence, it was much easier for China to engage in market-oriented reform and restructure its state-owned heavy industries at this time than, say, in the late 1970s and 1980s or even early 1990s. ${ }^{28}$ Again, in contrast, Russia's state-owned heavy industries were mostly abandoned or destroyed by their "shock therapy" approach to reform and the ensuing so-called "market forces" in the 1990s. China, however, took a more patient approach and leveraged its large domestic market to successfully build its colossal light industrial base and expand its purchasing power to sustainably finance its large-scale heavy industries.

China's national saving rate is nearly 50 percent and its aggregate investment rate is 45 percent; the inflows of foreign direct investment in manufacturing from industrial economies have been extensive since the mid 1990s, as has China's rapid advancement in heavy industrial technologies such as steel, ship-building, high-speed rail systems, and space programs-most of which are state-owned.

An important lesson learned from China's privatization experience (in comparison with Russia's) is that a nation should be extremely cautious in privatizing its state-owned enterprises. It is dangerous to blindly or indiscriminately privatize all industries before market conditions are ready. The market conditions for privatizing a particular industry are ready if and only if (i) the market is large enough to support similar-type private firms; (ii) private 


\section{Wen and Fortier}

firms in this industry are well developed and sufficiently competitive domestically or internationally in finance, management, and technological innovations; and (iii) privatization does not put national security at risk and key industries (such as natural resources) may be only merged or engaged in joint ventures as opposed to fully privatized. ${ }^{29}$

It is extremely costly to create a market and even more costly to create the regulatory institutions to regulate market activities. Without forceful and appropriate regulations, markets will malfunction and market forces can destroy social trust-which is the very foundation of the market itself. Yet the Washington consensus and the institutional theory have offered no instructions to developing nations on how to build market-specific regulatory institutions to prevent or mitigate the destructive power of market forces and corporate freedom, especially with regard to deregulation, liberalization, marketization, privatization, and democratization.

\section{CONCLUSION}

Poverty is always and everywhere a social coordination-failure problem. The problem arises because creating markets and the corresponding economic organizations (based on the principle of the division of labor) are extremely costly and require broad and intense coordination efforts and trust from all market participants. Thus, Wen (2016a) states that the "free" market is the most fundamental public good in a market economy, and its most fundamental pillar is social trust. The benefits of the market are largely social, while its costs (of creation and participation) are largely private.

Hence, development's first and foremost challenge is in overcoming both missing markets and missing market creators. Historically, a natural process of mass-market formation/ fermentation has been a lengthy evolutionary process initially accomplished mainly by a large and powerful merchant class that has acted collectively under a nationalistic mercantilist spirit backed fiercely by their government.

China's development experience has shown the world that the centuries-long Westernstyle "natural" and lengthy market-fermentation process can be dramatically accelerated and re-engineered by the government when it supplies the market creators-in place of the missing merchant class-yet without repeating the Western powers' old development path of primitive accumulations based on colonialism, imperialism, and the slave trade.

China's development experience suggests a new model of economic development: the New Stage Theory (NST) or "Embryonic" Development Theory (EDT). The NST is closely related to the old stage theory of List (1841), Marx (1867), and Rostow (1960) and the other schools of development theory, such as Structuralism and New Structuralism (Justin Yifu Lin) and the ISI and the "Big Push" theory of development (as advocated by Paul Rosenstein-Rodin in 1943 and Kevin M. Murphy, Andrei Schleifer, and Robert W. Vishny in 1989).

NST emphasizes that, for late-developing countries with a tremendous lag in reaching the technological frontier and despite the advantage of backwardness, repeating some of the earlier development stages of now-developed nations is necessary. Consider the study of mathematics: After thousands of years of development, the human race discovered math knowledge sequentially, from numbers to arithmetic to algebra to calculus etc. Although cal- 
culus is in today's first-year college textbooks, every generation of children must still repeat humanity's evolutionary process to learn math. They do not jump to calculus at age 6 , but instead start with learning numbers (with the help of their fingers, just as our ancestors did) and gradually move up the ladder to more advanced forms. Yet modern development theories focus almost exclusively on adoption of frontier technology or financial liberalization as the key to industrialization for agrarian societies, without realizing that supply does not create its own demand. The mode of mass production is not profitable when a mass market and mass distribution do not exist. So, industrialization is first and foremost a task of market creation. The creation of a mass market must always proceed through several major and distinctive stages - sequentially - with each stage facing its own specific challenges related to market failures and missing market creators. Hence, poverty and the development problem cannot be solved by political democracy, as so many expected or hoped for during the "Arab Spring." It also cannot be solved by an intense effort through "shock therapy" or a one-time colossal national investment boom facilitated by foreign aid or a top-down heavy-industry-based approach, as advocated by the old stage theories and the Washington consensus. Instead, successful economic development requires many rounds of sequential effort led by a powerful mercantilist government under political stability, coordinated between local and central governments, but that begins at the grassroots level.

The new institutional theory (e.g., Acemoglu and Robinson, 2012) suggests that the Industrial Revolution started in Great Britain, instead of 18th century China or India, because it was Great Britain that first developed inclusive political institutions (through the Glorious Revolution) and the rule of law. This view is misleading and inconsistent with historical facts. As economic historian Sven Beckert aptly put it, "The first industrial nation, Great Britain, was hardly a liberal, lean state with dependable but impartial institutions as it is often portrayed. Instead it was an imperial nation characterized by enormous military expenditures, a nearly constant state of war, a powerful and interventionist bureaucracy, high taxes, skyrocketing government debt, and protectionist tariffs-and it was certainly not democratic" (Beckert, 2014, p. xv).

Furthermore, the institutional theory cannot explain (i) why there are many democracies with pervasive economic stagnation and continuous political turmoil, such as Afghanistan, Egypt, Iraq, Libya, Pakistan, Thailand, Tunisia, and Ukraine; (ii) why there are ample extractive institutions that have been economically strong, such as Germany (1850 to World War II) and Soviet Russia (1860 to World War II); and (iii) modern-day Russia's dismal failure in economic reform under democracy and shock therapy, Japan's rapid industrialization during the Meiji Restoration, South Korea's economic takeoff in the 1960s-1980s under dictatorship, and Singapore's post-independence economic miracle; and (iv) the fact that, under identical political institutions, property rights, and the rule of law, there exist pockets of both extreme poverty and extreme wealth and both violent crime and obedience to the law in many cities and regions of the same country, including the United States.

The degree of industrialization is limited by the extent of the market a nation provides for its firms. Therefore, the fundamental reason Great Britain, instead of the politically more liberal Netherlands, kick-started the (first) Industrial Revolution in the late 18th century was 
because of its successful creation of the world's largest textile market and cotton supply chains, which made the nationwide adoption of the spinning jenny and factory system profitable and inevitable. Likewise, the fundamental reason the United States, instead of France or Germany, overtook Great Britain to become the next economic superpower was that the United States, with the help of its government, had created an even larger manufactured goods market in the 19th century, which nurtured the world's greatest inventors such as Thomas Edison and industrial giants such as Andrew Carnegie, Henry Ford, J.P. Morgan, John D. Rockefeller, and Cornelius Vanderbilt. ${ }^{30}$

What the NST suggests in general is that industrial policies and development strategies matter and are responsible for the failures and successes of nations when they attempt to escape poverty. Political institutions, which are endogenous to economic development, are not responsible, except in providing political stability to support commerce. In fact, many different political systems can provide such commerce-friendly political stability, such as monarchies, republics, autocracies, or meritocracies. Given that most nations and their governments do want to develop their economies and have tried very hard repeatedly in the past to industrialize, it is difficult to argue that their failures are due to the government's lack of incentives to develop because of vested interests under a non-democratic system (Acemoglu and Robinson, 2012). In fact, it is in the interest of the poor nation's government to develop if they want to stay in power. ${ }^{31}$ Unfortunately, many poor nations and their government leaders get stuck in the process of industrialization because of implementing the wrong industrial policies and development strategies, just as China did in its previous three failed attempts at industrialization. To be sure, although Western style democracy is not likely the precondition that will sustain China's growth, market mechanisms and good governance are.

Institutions are endogenous and built to facilitate the execution and implementation of developmental policies and strategies and to protect the fruits of industrialization. Therefore, it is reasonable to expect that China's "backward" financial and legal institutions will be history if China continues to develop based on its gradualist development strategy: move up the industrial ladder from light to heavy industries, from labor to capital-intensive production, from manufacturing to financial capitalism, and from a high-saving state to a consumeristic welfare state. China has had only 35 years of genuine industrialization, which can only be described as short when compared with 300 years of volatile capitalism in the Western world. China may require at least another 30 years or so to clearly demonstrate whether it can build a modern financial system to facilitate its enormous economy and a modern legal system to protect the fruits of its industrial revolution. Only then can China be judged more fairly and on a more equal footing with Western nations. ${ }^{32}$. 


\section{APPENDIX}

\section{Recent Regimes and Events in China}

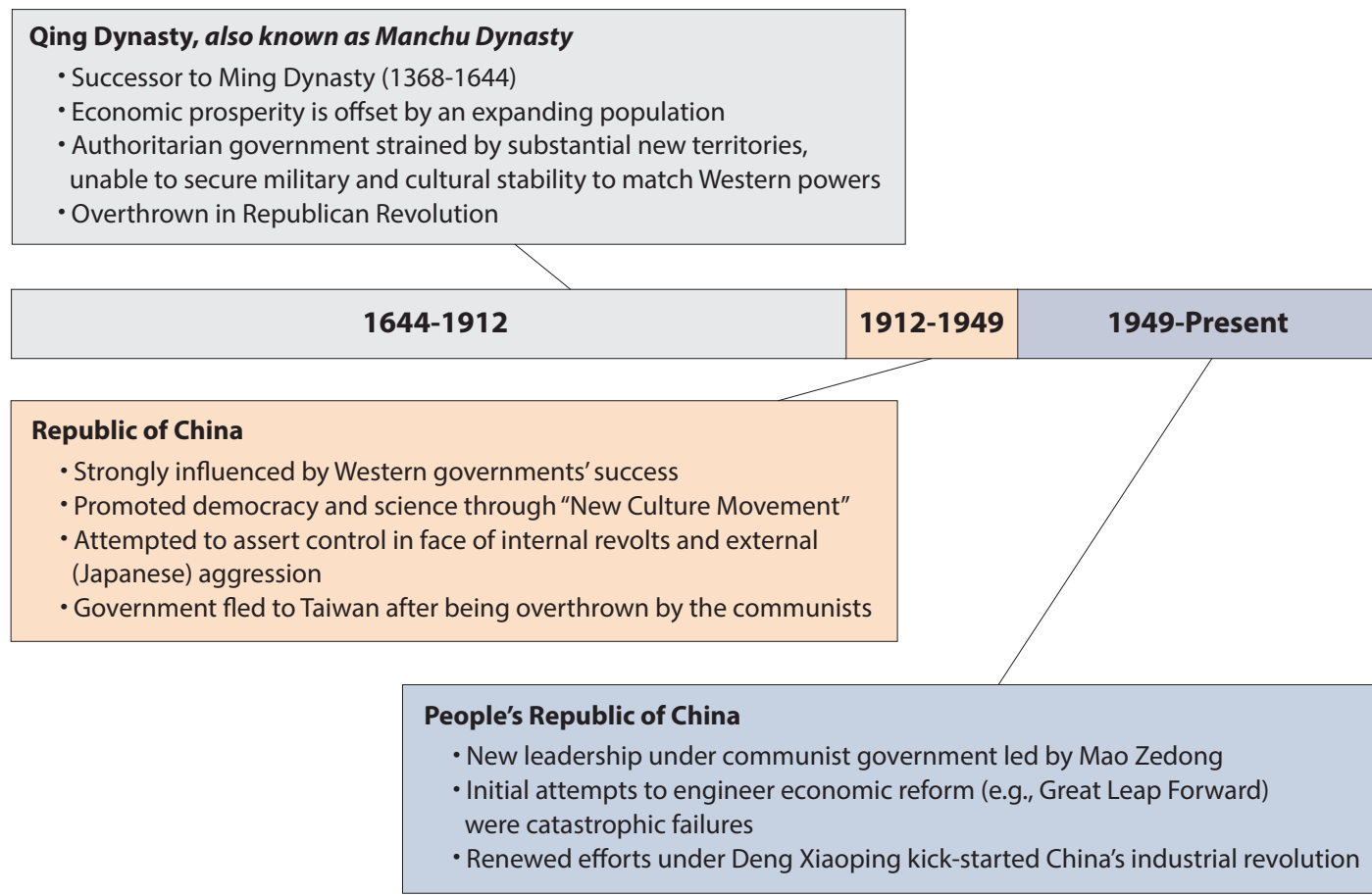

1842 China defeated by British in First Opium War.

1860 China defeated by British in Second Opium War; Qing monarchy attempts to establish modern navy and industrial infrastructure.

1895 China defeated by Japanese in Sino-Japanese War.

1900 Boxer Rebellion.

1911 Qing monarchy is deep in debt; social unrest leads to the Xinhai Revolution, which overthrows the monarchy and establishes Republic of China (the nation's first "inclusive" government).

1912 Republic of China commences under Sun Yat-sen, who is soon replaced by Yuan Shikai.

1919 May Fourth Movement: Students and workers protest China's acceptance of Treaty of Versailles, which relinquished land (formerly under German control) to Japan. Surge in Chinese nationalism.

1921 Chinese Communist Party organizes in Shanghai.

1937 Japan invades China.

1945 Mao outlines his "New Democracy." War with Japan ends.

1949 Communists / People's Liberation Army occupy Beijing and Shanghai. Mao Zedong proclaims founding of People's Republic of China. Chiang Kai-shek's government flees to Taiwan.

1950-1952 Land reforms implemented. 


\section{Wen and Fortier}

1953 Five-Year Plan of economic growth and development begins. Mutual Aid Teams organized in Chinese countryside. Chinese Communist Party Central Committee authorizes Agricultural Producers' Cooperatives.

1955-1956 Mao Zedong intervenes to speed up formation of rural Agricultural Producers' Cooperatives, greatly increasing their numbers, but severely disrupts agricultural production.

1958-1961 Great Leap Forward. Food crisis intensifies.

1966 Cultural Revolution begins. Little Red Book is published.

1967 Deng Xiaoping and Liu Shaoqi accused of crimes against Chinese Communist Party.

1969 U.S. partially lifts trade embargo against China.

$1972 \quad$ U.S. President Nixon visits China.

1973-1974 Deng Xiaoping "rehabilitated" as vice premier, addresses United Nations General Assembly, reappointed as vice chairman of Chinese Communist Party.

1976 Deng Xiaoping purged from Party; Mao Zedong dies.

1977 Deng Xiaoping, once restored to Party, begins push for major reforms.

1984 Deng Xiaoping tours Special Economic Zones and advocates for continued economic reform; U.S. President Reagan visits China.

1986 China becomes member of Asian Development Bank.

1989 Tiananmen Square incident.

1992 Deng Xiaoping visits Special Economic Zones in Shenzhen, leading to further economic reforms. China's military spending increases 13 percent. National Party Congress approves plans for Three Gorges Dam project. One million workers laid off from inefficient state-owned enterprises. At 14th National Party Congress, principle of "socialist market economic system" is promoted.

1993 Jiang Zemin appointed president of People's Republic of China.

1994 U.S. extends most-favored nation status to China, separating human rights and trade issues.

1995 China adopts its first banking laws, the Law of the People's Bank of China. China Construction Bank and Morgan Stanley launch China International Capital Corporation, first joint venture investment bank in China. China formally requests to join World Trade Organization.

1996 Kelon becomes first Chinese township enterprise listed on the Hong Kong stock exchange.

1997 Deng Xiaoping dies.

2001 China enters World Trade Organization.

2003 China surpasses U.S. as world's largest recipient of foreign direct investment. Four million families in China own automobiles.

2004 China becomes sixth-largest economy in the world. China publicizes several of its billionaires. Provisions to protect human rights and private property incorporated into Chinese constitution. China reaches 87 million internet users.

China replaces U.S. as Japan's largest trade partner, with foreign exchange reserves second only to Japan. End to global textile quotas leads to surge in exports from China to U.S.

2010 China becomes second-largest economy in the world.

2012 The Three Gorges Dam, the world's largest power station, becomes fully functional after 18 years of construction at a cost of 148 billion yuan ( $\$ 22.5$ billion).

SOURCE: Sullivan (2007), Bruton, Lan, and Lu (2000), and Wen (2016a) and the references therein. 


\section{NOTES}

1 For a profile of a typical Chinese local government official and his role as a "public merchant," see Chapter 6 in Wen (2016a).

2 Also see Wen's (2016b) short article in the Federal Reserve Bank of St. Louis The Regional Economist.

3 In 1949, China's peasant population as a share of its total national population remained at more than 90 percent, not much changed since the Second Opium War around 1860. Average life expectancy remained as low as 30 to 35 years and the literacy rate was only 15 to 25 percent.

4 For example, the young Mao Zedong was a high-ranking official member of the republican government in the early 1920 s.

5 One extremely important legacy of Mao's era, seldom mentioned and appreciated in the existing literature, is the critical level of "social capital" (including social trust in general and farmers' abilities to organize themselves) and a unified national market with a potential size of four times that of the U.S. market. As mentioned earlier and discussed later, social trust and national unity are fundamental pillars of a unified "free" market on which the division of labor is based.

6 The first time was in 1966 at the start of the Cultural Revolution, and the second was around 1976 after the Cultural Revolution but before Mao's death. See Vogel (2013).

7 See Marangos (2007) and Williamson (2004).

8 To conserve space, this article does not provide a systematic analysis on why such developmental strategies fail. Interested readers are referred to Wen (2016a) for such an analysis and critical evaluation of these development policies.

9 According to Studwell (2013, p. 17), "In the 1920s, when 85 percent of Chinese people lived in the countryside, life expectancy at birth for rural dwellers was 20-25 years. Three quarters of farming families had plots of less than one hectare, while perhaps one-tenth of the population owned seven-tenths of the cultivable land."

${ }^{10}$ During the Great Leap Forward, there were 6 million village factories created. But most of them were forced to shut down after 1962 due to the great famine. But a fraction of them survived because of the protection of local villagers. The initial 1.52 million village firms in 1978 were the legacy of the Great Leap Forward and served as the catalyst of China's long-awaited rural industrialization. Of course, the benefits achieved by Mao's communist regime do not deny or excuse the hardships and crimes perpetrated against the Chinese people_-including violating human rights during the Cultural Revolution. Actually, the Cultural Revolution might have destroyed some of the social capital (mostly social trust) built by Mao in the 1950s and early 1960s. However, this loss of trust did not occur in the rural areas. And it was that sustained social capital in the rural areas that was the most critical for setting off China's proto-industrialization.

11 See Mendels's $(1972,1981)$ analysis of the phenomenon of proto-industrialization in European economic history and the literature stimulated by this. What is most puzzling about China's proto-industrialization is that it did not occur in Qing Dynasty China or during the Republic era, despite a market system and well-protected private property rights in the rural areas.

${ }^{12}$ Housing has been one of the major areas of growth during China's industrialization. We refer interested readers to "The Great Housing Boom of China," a working paper by Chen and Wen (2015, forthcoming in American Economic Journal: Macroeconomics).

13 "The putting-out system exploited the benefits of the division of labor to the full" (from the Oxford Encyclopedia of Economic History, 2003, p. 101; see also International Encyclopedia of the Social Sciences, 2008). The putting-out system was family-based domestic manufacturing prevalent in the rural areas of Western Europe during the 17th and 18th centuries. It appeared even earlier in 16th century Italy. Domestic workers typically owned their own primitive tools (such as looms and spinning wheels) but depended on merchant capitalists to provide them with the raw materials to fashion products that were deemed the property of the merchants. Semi-finished products would be passed on by the merchant to another workplace for further processing, while finished products would be taken directly to market by the merchants. Even independent domestic craftsmen working on their own also relied on merchants to introduce their products in distant markets. 


\section{Wen and Fortier}

14 Under the putting-out system, tools of production have often been owned by the peasant households, but sometimes by the merchants who have rented them to the peasant workers.

15 Mercantilism is economic nationalism for the purpose of building a wealthy and powerful state based on commerce and manufacturing. It has sought to enrich the country by restraining imports of manufactured goods and encouraging exports of manufactured goods. In short, it emphasizes and promotes manufacturing over agriculture and commercialism over physiocracy. However, most of the literature on mercantilism views it simply as a form of protectionism or pure pursuit of trade surplus or gold reserves and overlooks the key point of commerce and, again, manufacturing. An economy relying solely on agriculture has nothing to benefit from mercantilism. But a nation intending to build on manufacturing can benefit greatly from mercantilism because manufacturing stimulates the division of labor and generates the economies of scale. The historical importance of mercantilism in the 16th to 18th centuries in Europe as the prototype of capitalism and the key step leading to the British Industrial Revolution can never be emphasized enough. Indeed, the promotion of manufacturing inherent in mercantilism has seldom been appreciated by classical economists, including Adam Smith and David Ricardo, unlike Friedrich List (1841). One example of the impact of mercantilism on economic development is the 19th century American industrial revolution based on the "American System," which was an economic development strategy envisioned by Alexander Hamilton (1755-1804) in 1791 and vigorously implemented throughout the 19th century to win global competition with Great Britain. (Hamilton's idea was not immediately adopted in the 1790s and the initial decade of the 1800s.) It consisted of several mutually reinforcing parts: high tariffs to protect and promote the American infant manufacturing sector in the North; a national bank to foster commerce, stabilize the currency, and rein in risktaking private banks; maintenance of high public land prices to generate federal revenue; and large-scale federal subsidies for roads, canals, and other infrastructures to develop a unified national market-financed through tariffs and land sales. Also see Ha-Joon Chang's (2003) Kicking Away the Ladder: Development Strategies in Historical Perspective for many examples of mercantilism and the historical role it played in Western economic development. However, many Latin American countries in the middle 20th century also adopted various forms of mercantilism (e.g., import substitution industrialization) but failed miserably. The reasons behind such successes and failures are precisely what Wen's (2016a) book is about.

${ }^{16}$ Some historians believe that slavery and trans-Atlantic trade helped finance the British Industrial Revolution. Plantation owners, shipbuilders, and merchants who were connected with the slave trade accumulated vast fortunes that established banks and large manufactures in Europe and expanded the reach of capitalism worldwide. For scholarly articles on the critical contributions of slavery and trans-Atlantic trade to the Industrial Revolution, see, e.g., Williams (1994). Kriedte, Medick, and Schlumbohm (1981, p. 131) provides a related perspective: "For England, which was politically and militarily the most successful country, the 'virtual monopoly among European powers of overseas colonies,' established during the phase of proto-industrialization, was one of the central preconditions which carried proto-industrialization beyond itself into the Industrial Revolution." Economic historians Pomeranz and Topik (2013, p. 104) argue that opium trade "not only helped create Britain's direct [trade] surplus with China, but made possible even the larger surplus with India. Without those surpluses, Britain could not have remained the West's chief consumer and financer, and the Atlantic economy as a whole would have grown much more slowly."

17 With China's institutional arrangement of public land ownership and the administrative power of local governments (a legacy of Mao's communism), farmers and peasants were able and willing to pool their savings to form the initial capital (cash and land assets) necessary for an initial investment in an establishment that by design was collectively owned, with profits and work opportunities equally shared among village farmers. Although land had been leased to individual families since 1978 under the family-responsibility system, the nature of the public ownership of land had not changed; acquiring land for industrial purposes, then, was not a great hurdle for the village farmers and the local governments. The managers of such collectively owned establishments were often the village officials, who were often democratically elected and viewed as natural leaders (China's earliest CEOs). Although Deng disbanded the communes that had been created under Mao's regime, the legacy of the Great Leap Forward and its communization movement made it easy to reintroduce collectively owned organizations. The high degree of trust among these village families and the leadership of the local governments enabled Chinese farmers to overcome the prohibitive transaction costs of contracting in an agrarian society where the legal system and law enforcement were lacking. In essence, they trusted fair income distribution and risk-sharing and credit payments.

18 See the boxed insert on village firms for more details. The source is Wen (2016a) and the references therein. For the original data, see Zhang and Zhang (2001 [in Chinese], Appendix Table 1).

${ }^{19}$ But with one critical difference: Chinese farmers in the 1980 s were experienced with self-organizational skills and endowed with social capital gained through Mao's Great Leap Forward and rural corporative movements. 
${ }^{20}$ In the 16th to 18th centuries in Europe, the lack of social trust and the associated transaction costs in forming corporations in rural areas were mitigated and overcome by the entrepreneurial, risk-taking, profit-seeking merchants, who were less financially constrained and more experienced in long distance trade. But, again, it took centuries for Europe in general and England specifically to form such a powerful merchant class through commercialism, colonialism, imperialism, mercantilism, and the trans-Atlantic slave trade. This process of forming markets in Europe, England, and elsewhere around the globe under colonialism can be thought of as "natural market fermentation," where the key agents are the powerful merchants. This global market creation process is also extremely costly and requires that trade be secured and enforced by military pressure. European overseas explorations and trade were extremely capital-intensive because of the colossal costs and risks involved. Most long-distance trade carried out by European merchants included armed trade and was endorsed and supported militarily by their governments. This context is captured in the words of the famous Dutch merchant and warrior Jan Pieterszoon Coen to the Dutch monarch: "Your Honours should know by experience that trade in Asia must be driven and maintained under the protection and favour of Your Honours' own weapons, and that the weapons must be paid for by the profits from the trade; so that we cannot carry on trade without war, nor war without trade" (see Bown, 2010, p. 7).

${ }^{21}$ As important as it was in further stimulating China's labor-intensive industry, many economists wrongly attribute China's rapid industrialization to its successful entrance into the WTO. India and Indonesia, for example, both became members of the WTO in early 1995, six to seven years before China did in late 2001. Yet WTO membership did not trigger an industrial revolution in these two countries. The key difference between China and India or Indonesia was that China had already begun its industrial revolution at the time of its WTO entry, whereas India had not. Hence, WTO membership meant very different things for these countries: It meant a larger export market for mass-produced Chinese goods, but simply more inflow of foreign-produced goods for India and Indonesia.

${ }^{22}$ Compared with wool and other types of natural fibers, cotton is also more easily manipulable for the production of clothing.

${ }^{23}$ More details can be found in Wen (2016a). To illustrate, the United States became the world's textile superpower (superseding Great Britain) around the middle of the 19th century before it became the global manufacturing superpower in the late 19th century; Japan became a textile superpower in the early 20th century before it became a manufacturing superpower around the middle of the 20th century; China became the world's textile superpower in 1995 before it launched its second industrial revolution in heavy industries. These same development steps were taken by France, Germany, South Korea, Taiwan, Hong Kong, and many other economies, all with dramatically different geographic locations, population sizes, and cultural and institutional environments.

24 This is essentially the view of Friedrich List (1841) as established in The Natural System of Political Economy. Even institutions in developed nations (such as the U.S. Department of Energy) maintain tight connections with foreign policy and international politics.

${ }^{25}$ China waited until 1997-98 to start substantially reforming its state-owned enterprises (SOEs); by then, China had essentially already finished its first industrial revolution. Because China's SOEs were located mostly in urban areas and large cities, such a measured development strategy enabled the SOEs to perform at least two important functions in facilitating China's economic transition and industrialization: (i) to maintain and stabilize urban employment during the rural-based proto-industrialization and first industrial revolution; and (ii) to play a leadership role in promoting and transferring more advanced production technologies to rural industries. (China's rural industries received most of their technology and engineers from SOEs in nearby cities.) But once rural industries caught up with SOEs in technology and China broadly finished its first industrial revolution in mass-producing labor-intensive light consumer goods, the historical role of China's small to medium-sized SOEs (which were based on mass production technology to begin with) was finished and naturally yielded to newly formed but more-productive and better-managed private or collective enterprises. During the first 2 years of SOE reform between 1998 and 2000, about 21.4 million SOE workers were laid off, mostly in the textile, mining, military defense, and machinery sectors. However, because of prohibitive costs in finance and technological barriers to form large-scale private heavy industries, China privatized only the small to medium-sized SOEs, which could be easily absorbed or substituted by the private sector. But it kept its large heavy-industrial SOEs under the so-called "grasping the large and letting go of the small" nationwide SOE reform. This by no means implied lack of reform for the remaining large SOEs. The government forced the remaining large heavy-industrial SOEs to reform management structure, upgrade technologies, and confront domestic and international competition. The success of China's high-speed rail companies is a good example of such a measured and targeted SOE reform strategy.

${ }^{26}$ The private patent system has not been as important in the advancement of science and technology as institutional economists have claimed — not even during the British Industrial Revolution (see, e.g., Boldrin and Levine, 2008, 


\section{Wen and Fortier}

and Mokyr, 2008). In fact, Boldrin and Levin use historical evidence (e.g., the inventor James Watt and his steam engine) to argue that intellectual property rights have hindered innovation rather than stimulated it throughout history.

27 See, e.g., Lau, Qian, and Roland (2000). Also see the literature's discussions on China's "grasping the large, letting go of the small" reform strategy implemented since 1997 for its heavy industries. For a definition, see http://en.wikipedia.org/wiki/Grasping_the_large,_letting_go_of_the_small.

${ }^{28}$ For example, some of China's military defense companies shifted from manufacturing weaponry and tanks to manufacturing durable consumer goods such as motorcycles and automobiles in the early 1990s. The world's largest producer of high-speed trains used to be a money-losing firm that produced steam engines back in the 1960s under Mao.

29 Judged by such criteria, China's privatization of small to medium-sized firms such as labor-intensive textile firms was extremely successful, but its market-based reforms in the education and healthcare sectors were disastrous. In retrospect, China should have waited until private hospitals and clinics (or private schools) were well developed and sufficiently competitive with their public counterparts before introducing profit-motivated reforms into these public sectors. Such a waiting period could also allow the government to develop sophisticated regulations in such important welfare-sensitive areas. Hence, as China is currently undergoing its second industrial revolution, it must be extremely careful in taking a measured, dual-tracked, and gradualist approach to financial-sector reforms and privatization of its heavy industries. The danger and risk of a Russian-style collapse under "shock therapy" still exists.

${ }^{30}$ During its first industrial revolution period in 1815-1860, the United States spent $\$ 188$ million to build canals, 73 percent of which was financed by state and local governments (see Chandler, 1977). In the same period, the territory of the United States expanded enormously, after taking Texas and California from Mexico. Then, after preventing the secession of the cotton-rich Southern states through the Civil War and a long period of government-led railroad expansion, the United States successfully created the largest unified domestic market in the world.

${ }^{31}$ For example, Indian leader Jawaharlal Nehru (in 1946) said, “No country can be politically and economically independent, even within the framework of international interdependence, unless it is highly industrialized and has developed its power resources to the utmost." Chinese leader Mao Zedong (in 1943) said similarly that "Without the establishment of heavy industries in China, there can be no solid national defense, no well-being for the people, no prosperity and strength for the nation." (See Lin, 2009, p. 20.)

32 In other words, universal suffrage is not the same thing as the rule of law, the rule of law is not the same thing as the market mechanism, and the market mechanism is not the same thing as private property rights. For example, research scientists working for Pfizer (one of the largest U.S. pharmaceutical companies) do not own their intellectual property at all, but they still work very hard to develop new drugs. The United States finished its second industrial revolution during 1880-1940 without universal suffrage.

\section{REFERENCES}

Acemoglu, Daron and Robinson, James. Why Nations Fail: The Origins of Power, Prosperity, and Poverty. New York: Crown Business, 2012.

Agence France-Presse. "China Drives Growth in Patent Applications Worldwide." Industry Week, December 16, 2014. http://www.industryweek.com/global-economy/china-drives-growth-patent-applications-worldwide.

Beckert, Sven. Empire of Cotton: A Global History. Knopf, 2014.

Blumenthal, David and Hsiao, William. "Privatization and Its Discontents-The Evolving Chinese Health Care System." New England Journal of Medicine, 2005, pp. 1165-70; http://dx.doi.org/10.1056/NEJMhpr051133.

Boldrin, Michele and Levine, David K. Against Intellectual Monopoly. Cambridge: Cambridge University Press, 2008.

Bown, Stephen R. Merchant Kings: When Companies Ruled the World, 1600-1900. Macmillan, 2010.

Bruton, Garry D.; Lan, Hailin and Lu, Yuan. "China's Township and Village Enterprises: Kelon's Competitive Edge." Academy of Management Executives, 2000, 14(1), pp. 19-29; http://dx.doi.org/10.5465/ame.2000.2909834.

Chandler, Alfred D. Jr. The Visible Hand: The Managerial Revolution in American Business. Cambridge, MA: Harvard University Press, 1977. 
Chang, Ha-Joon. Kicking Away the Ladder: Development Strategies in Historical Perspective. London: Anthem Press, 2003.

Chen, Kaiji and Wen, Yi. "The Great Housing Boom of China." Federal Reserve Bank of St. Louis Working Paper 2014-022B, 2014 (updated September 2015); https://research.stlouisfed.org/wp/more/2014-022.

Chinese National Committee on Large Dams. "Three Gorges Project." 2010; http://www.chincold.org.cn/dams/rootfiles/2010/07/20/1279253974143251-1279253974145520.pdf.

Cook, lan G. and Dummer, Trevor J.B. "Changing Health in China: Re-evaluating the Epidemiological Transition Model." Health Policy, 2004, 3, pp. 329-43; http://dx.doi.org/10.1016/j.healthpol.2003.07.005.

Estévez-Abe, Margarita. Welfare and Capitalism in Postwar Japan: Party, Bureaucracy, and Business. Cambridge: Cambridge University Press, 2008; http://dx.doi.org/10.1017/CBO9780511510069.

Gerschenkron, Alexander. Economic Backwardness in Historical Perspective. Cambridge, MA: Belknap Press of Harvard University Press, 1962.

International Encyclopedia of the Social Sciences. "Putting-Out System," 2008; retrieved from http://www.encyclopedia.com/doc/1G2-3045302138.html.

Jones, William C. and Freeman, Marsha. "Three Gorges Dam: The TVA on the Yangtze River." Schiller Institute: Great Infrastructure Projects, 2001; http://www.schillerinstitute.org/economy/phys_econ/phys_econ_3_gorges.html.

Kriedte, P.; Medick, H. and Schlumbohm, J. Industrialization before Industrialization: Rural Industry in the Genesis of Capitalism. Cambridge: Cambridge University Press, 1981, p. 131.

Landes, David S. The Wealth and Poverty of Nations: Why Some Are So Rich and Some So Poor. New York: Norton, 1999.

Lau, L.; Qian, Y. and Roland, G. “Reform Without Losers: An Interpretation of China's Dual-Track Approach to Transition." Journal of Political Economy, 2000, 108, pp. 120-43; http://dx.doi.org/10.1086/262113.

Lin, Justin Y. Economic Development and Transition: Thought, Strategy, and Viability. Cambridge: Cambridge University Press, 2009; http://dx.doi.org/10.1086/262113.

List, Friedrich. The Natural System of Political Economy. London: Longmans, Green, and Co, [1841] 1909.

Lu, Ding. “China's Banking Sector Meeting the WTO Agenda." Discussion Paper No. 5, China Policy Institute, University of Nottingham, April 2006.

Marangos, John. "The Shock Therapy Model of Transition." International Journal of Economic Policy in Emerging Economies, 2007, 1(1), pp. 88-123; http://dx.doi.org/10.1504/IJEPEE.2007.015583.

Marx, Karl. Capital. Volume 1. 1867.

Mendels, Franklin F. "Proto-industrialization: The First Phase of the Industrialization Process." Journal of Economic History, March 1972, 32(1), pp. 241-61; http://dx.doi.org/10.1017/S0022050700075495.

Mendels, Franklin F. Industrialization and Population Pressure in Eighteenth-Century Flanders. New York: Arno Press, 1981.

Mokyr, Joel. "The Institutional Origins of the Industrial Revolution," in Elhanan Helpman, ed., Institutions and Economic Performance. Cambridge, MA: Harvard University Press, 2008, pp. 64-119.

Mufson, Steven. "The Three Gorges Dam." Washington Post, November 9, 1997; http://www.washingtonpost.com/wp-srv/inatl/longterm/yangtze/yangtze.htm.

Murphy, Kevin M.; Shleifer, Andrei and Vishny, Robert W. "Industrialization and the Big Push." Journal of Political Economy, October 1989, 97(5), pp. 1003-26; http://dx.doi.org/10.1086/261641.

Oi, Jean C. "Fiscal Reform and the Economic Foundations of Local State Corporatism in China." World Politics, 1992, 45(1), pp. 99-126; http://dx.doi.org/10.2307/2010520.

Oxford Encyclopedia of Economic History. Oxford: Oxford University Press, 2003.

Pomeranz, Kenneth and Topik, Steven. The World That Trade Created. Third edition. ME Sharpe, 2013.

Qiu, Larry D. "China's Textile and Clothing Industry." Unpublished manuscript, Hong Kong University of Science and Technology, 2005. 


\section{Wen and Fortier}

Roll, Eric. An Early Experiment in Industrial Organization: Being a History of the Firm of Boulton \& Watt, 1775-1805. Frank Cass and Co, 1968.

Rosenstein-Rodan, Paul. "Problems of Industrialization of Eastern and South-Eastern Europe." Economic Journal, 1943, 53(210/211), pp. 202-11; http://dx.doi.org/10.2307/2226317.

Rostow, Walt W. The Stages of Economic Growth: A Non-Communist Manifesto. Cambridge: Cambridge University Press, 1960.

Smith, Adam. The Wealth of Nations. London: JM Dent \& Sons, 1937 [1776].

Studwell, Joe. How Asia Works: Success and Failure in the World's Most Dynamic Region. Grove Press, 2013.

Sullivan, Lawrence R. Historical Dictionary of the People's Republic of China. Lanham, MD: Scarecrow Press, 2007.

Vogel, Ezra F. Deng Xiaoping and the Transformation of China. Cambridge, MA: Belknap Press / Harvard University Press, 2013.

Wen, Yi. The Making of an Economic Superpower: Unlocking China's Secret of Rapid Industrialization. Singapore: World Scientific Publishing, 2016a; http://dx.doi.org/10.1142/9885. [In Chinese: 《伟大的中国工业革命——“发展政治 经济学"一般原理批判纲要》, 清华大学出版社, 2016;

https://world.tmall.com/item/535482239543.htm?spm=0.0.0.0.sDNoZi\&id=535482239543].

Wen, Yi. “China's Rapid Rise." Federal Reserve Bank of St. Louis The Regional Economist, April 2016b, 24(2), pp. 8-14.

Williams, Eric. Capitalism and Slavery. Chapel Hill: University of North Carolina Press, 1994.

Williamson, John. "The Washington Consensus as Policy Prescription for Development." Lecture in the series "Practitioners of Development," delivered at the World Bank, January 13, 2004; https://piie.com/publications/papers/williamson0204.pdf.

World Bank. "Connecting to Compete 2014: Trade Logistics in the Global Economy-The Logistics Performance Index and Its Indicators." Washington, DC: World Bank, 2014; https://openknowledge.worldbank.org/bitstream/handle/10986/20399/904190WPOLPIORO0Box385316B0OPUBLIC0.pdf?sequence=1\&isAllowed=y.

Zhang, Yi and Zhang, Song-song. "A Short History of China's Village Enterprises." [In Chinese: 张毅、张颂颂编著, 《中国乡镇企业简史》，中国农业出版社 ] 2001. 